\title{
A NECESSIDADE DE ATUAÇÃO RESOlUtIVA dO MINISTÉRIO PÚBLICO NA RESOLUÇÃO DOS CONFLITOS AMBIENTAIS FRENTE AOS RESULTADOS SOBRE AS AÇÕES CIVIS PÚBLICAS AJUIZADAS NO TRIBUNAL DE JUSTIÇA DE SÃO PAULO
}

\section{THE NEED FOR RESOLUTIVE ACTION OF THE PUBLIC MINISTRY IN THE RESOLUTION OF ENVIRONMENTAL CONFLICTS REGARDING THE RESULTS ON PUBLIC CIVIL ACTIONS ADJUSTED IN THE COURT OF JUSTICE OF SÃO PAULO}

Silvana Raquel Brendler Colombo ${ }^{1}$

Resumo: O Ministério Público brasileiro tem uma posição destacada na defesa dos interesses da sociedade em matéria ambiental, especialmente porque é um dos legitimados ativos da Ação Civil Pública. Nesta perspectiva, este artigo analisa os resultados sobre as Ações Civis Públicas Ambientais, julgadas pelas Câmaras Reservadas à matéria ambiental do Tribunal de Justiça de São Paulo em 2017, especialmente para identificar o tempo médio de duração de tramitação das ACPs e compará-lo com o tempo médio de resolução consensual dos conflitos na área ambiental. Por fim, defende a consolidação da postura resolutiva do Ministério Público, ao invés da postura demandista, como forma de conferir efetividade à resolução dos conflitos ambientais. Trata-se de uma pesquisa qualitativa, pois se optou pela abordagem empírica do objeto.

Palavras-chave: Ação Civil Pública. Atuação Resolutiva.Conflitos ambientais. Ministério Público. Atuação Resolutiva

Abstract: The Brazilian Public Prosecutor's Office has a prominent position in defending the interests of society in environmental matters, especially because it is one of the legitimate assets of Public Civil Action. In this perspective, this article analyses the results on the Environmental Public Civil Actions, judged by the Chambers Reserved for environmental matters of the Court of Justice of São Paulo in 2017, especially to identify the average duration of processing of the PCA (ACPs) and compare it with the average time to resolve conflicts in the environmental area. Finally, it defends the consolidation of the resolutive position of the Public Prosecutor's Office, instead of

\footnotetext{
${ }^{1}$ Professora do curso de direito da URI, Doutora em Direito PUC PR, Mestre em Direito UCS. Universidade Regional Integrada do Alto Uruguai e das Missões - URI, Rio Grande do Sul. Brasil. E-mail: silcolombo@uri.edu.br
} 
the demanded posture, as a way of conferring effectiveness to the resolution of environmental conflicts. This is a qualitative research, because we opted for the empirical approach of the object.

Keywords: Environmental conflicts. Public Civil Action. Public Ministry. Performance.

\section{INTRODUÇÃO}

Inicialmente, cabe pontuar que a previsão da proteção constitucional do ambiente foi o divisor de águas para Direito Ambiental. Primeiro, devido ao estabelecimento do dever de não degradar o meio ambiente, com força obrigatória e de ordem pública, o que levou à criação de instrumentos de tutela reparatória e sancionatória postos à disposição do Estado e também dos cidadãos. Segundo, porque a tutela ambiental é elevada ao nível de um direito fundamental, em pé de igualdade com outros direitos previstos na Constituição.

Além da Constituição, outro ponto que merece ser apontado é a atuação do Ministério Público na defesa dos interesses da sociedade em matéria ambiental, em especial no processo coletivo, pois ao órgão ministerial é reconhecido o poder de provocar o exercício da jurisdição ambiental. A sua atuação ocorre na esfera judicial, por meio da Ação Civil Pública, e na esfera extrajudicial, especialmente por meio do Termo de Ajustamento de Conduta, no qual o suposto infrator ambiental assume compromissos para se ajustar à lei e, se o dano já ocorreu, a repará-lo mediante restauração do status quo, compensação e/ou indenização.

Não há dúvida de que tanto a Ação Civil Pública quanto o Termo de Ajustamento de Conduta são importantes na tutela ambiental. Entretanto, é consabido que o Judiciário está sobrecarregado de processos, o que ocasiona a demora na tramitação das ACPs e também de sua execução, que enfrenta obstáculos ligados à fiscalização de seu cumprimento.

Nesse sentido, este artigo dedica-se à análise da Ação Civil Pública, instituída pela Lei $\mathrm{n}^{\circ}$ 7.347/1985 e acolhida pelo artigo 129, inciso III, da Constituição da República, cujo objetivo principal é a tutela dos direitos difusos, coletivos e individuais homogêneos. Busca-se proceder a um levantamento de dados sobre as Ações Civis Públicas Ambientais, julgadas pelas Câmaras Reservadas à matéria ambiental do Tribunal de Justiça de São Paulo em 2017, especialmente para identificar o tempo médio de duração de tramitação das ACPs e compará-lo com o tempo médio de resolução consensual dos conflitos na área ambiental. 
Devido ao seu protagonismo do Ministério Público na área ambiental, a parte final deste artigo expõe estudo do perfil constitucional do Ministério Público, o demandista, que atua no plano jurisdicional, e também o resolutivo, que atua no plano extrajudicial. O relato de uma experiência brasileira na resolução consensual de conflitos ambientais finaliza este capítulo.

Como a definição de método está diretamente relacionada ao problema de pesquisa, às hipóteses e aos objetivos, optou-se como método de abordagem para desenvolver o tema escolhido, o método dedutivo. As fontes de pesquisa utilizadas foram livros sobre o tema, artigos de autores nacionais e estrangeiros, jurisprudência e a legislação. O critério de seleção dos autores foi o temático, e, nesse sentido, priorizou-se por aqueles que já abordaram esse tema de forma clara e satisfatória.

Trata-se de uma pesquisa qualitativa e, nessa perspectiva, depois da leitura da bibliografia selecionada e a revisão bibliográfica, investiu-se na abordagem empírica do objeto. Como instrumento de coleta de dados, foi o escolhido o levantamento de dados, cuja amostra é de pequena grandeza, sobre as ACPS ambientais julgadas em 2017 junto às Câmaras Reservadas ao meio ambiente do TJ/SP.

\section{CONFLITOS AMBIENTAIS}

Antes de esclarecer o conceito de conflito ambiental que será adotado nesta pesquisa, convém pontuar que as sociedades, as organizações e os relacionamentos interpessoais estão sujeitos a experimentar a cooperação ou o conflito em suas interações diárias. Nessa perspectiva, "qualquer grupo social, qualquer sociedade histórica pode ser definida em qualquer momento de acordo com as formas de conflito e de cooperação entre os seus diversos atores", de acordo com Bobbio, Matteucci, Pasquino (1998, p.225).

No modelo de interação baseado na cooperação, o cumprimento das obrigações ocorre de forma espontânea, já que a ação dos indivíduos ou grupos está direcionada para interesses convergentes. Não há resistência aos direitos de determinada pessoa, em outras palavras, é um estágio de harmonia, no qual as partes envolvidas pautam suas ações por meio do diálogo e da colaboração. Mas o processo interacional, construído por duas ou mais pessoas, grupos ou organizações sociais, é marcado predominantemente por interações antagônicas e objetivos diversos, o que os coloca em situação de confronto. (QUINTANA RAMíREZ, s/d).

Nesta perspectiva, Yarn (1999, p. 113) define conflito como "um processo ou estado em que duas ou mais pessoas divergem em razão de metas, interesses ou objetivos individuais percebidos como mutuamente incompatíveis". Ao conflito pode ser atribuída uma conotação 
negativa ou positiva. No primeiro caso, ele está associado à ideia de disputa e de perda para ao menos uma das partes. Na segunda situação, o conflito é encarado como um fato da vida, ou seja, como um fenômeno natural nas relações sociais. É percebido como uma oportunidade de mudanças, visto que se extrai do conflito o que ele tem de melhor: a capacidade de gerar resoluções construtivas e de compreensão entre as partes² (PINHO, 2009; CNJ, 2017).

Deutsch (2004), na obra The Resolution of Conflict: Constructive and Destructive Processes, menciona que os processos de resolução de conflitos podem ser classificados em destrutivos ou construtivos. Nos processos destrutivos, a relação processual entre as partes é encerrada com o enfraquecimento ou rompimento da relação social subjacente à disputa em decorrência da forma ineficiente de sua condução. Diversamente, nos processos construtivos, as partes terminam a relação processual com fortalecimento da relação social preexistente à disputa. Nesta perspectiva, os magistrados, mediadores ou árbitros que conduzem o processo devem engajar as partes para que resolvam de forma proativa as questões, sem atribuição de culpa ou estímulo à ideia de vencedor e perdedor ${ }^{3}$. Em síntese, inerente ao conflito está o seu potencial criativo e construtivo, como condição necessária para a construção do consenso, ou seja, ele é sinônimo de crise e de oportunidade. (GALTUNG, 2007; LEDERACH, 2012).

Por sua vez, considerando que o termo "ambiental" faz referência a todo processo que expressa uma relação entre a natureza e a cultura, o conflito ambiental ocorre no processo de apropriação e transformação da natureza pelo homem, bem como dos sistemas tecnológicos que nela intervêm. Esse conflito pode resultar do choque de interesses entre aqueles que causam um problema ambiental e aqueles que sofrem as consequências negativas deste ou do desacordo ou disputa acerca da distribuição e o uso dos recursos naturais entre os habitantes de um dado território. Nesta última situação, o conflito gira em torno da propriedade ou posse sobre os recursos naturais produzidos pelas pessoas, comunidade e Estados, para fins de satisfazer suas necessidades. (QUINTANA RAMIREZ, s/d; CORANTIOQUIA, 2001).

Coaduna com este posicionamento Little (2001, p.107), ao definir os conflitos como "disputas entre grupos sociais derivados dos distintos tipos de relação que eles mantêm com seu meio natural"; em síntese, eles provêm da relação que estabelece entre homem e natureza. Nesse

\footnotetext{
${ }^{2}$ Embora alguns autores, tais como o Professor Morton Deutsh, em sua obra The Resolution of Conflict: Constructive and Destructive Processes, tratem o conceito de conflito e disputa como iguais, do ponto de vista técnico, há uma distinção importante. A disputa existe somente após a propositura da demanda, que pressupõe a existência de um conflito. Já o conflito pode existir sem uma disputa. (YARN, 1999).

${ }^{3}$ No mesmo sentido, ver Zamorra y Castillo (1991).
} 
sentido, os conflitos ambientais podem ocorrer em torno de três dimensões. A primeira é o controle dos recursos naturais, que envolve a dimensão política, como a distribuição dos recursos naturais, a dimensão social, como a disputa de acesso a recursos naturais, e dimensão jurídica, que envolve a disputa formal de acesso a recursos naturais, por exemplo, conflito de patente. A segunda são os impactos sociais gerados pela ação do homem, materializada sob a forma de contaminação (vazamento de óleo), esgotamento dos recursos (lençóis freáticos) ou degradação dos ecossistemas (a desertificação). A última trata sobre os conhecimentos na área ambiental, por exemplo, os conflitos em torno de lugares sagrados e a percepção dos grupos sociais sobre os riscos (usinas nucleares).

Diversamente da definição de conflito ambiental apresentada por Little (2001), que circunda em torno do uso, controle ou acesso aos recursos naturais, para Zhouri et al. (2005), o conflito envolve os grupos sociais e a sua percepção em relação aos direitos territoriais. Neste mesmo viés, Acselrad (2004, p. 26) vê o conflito ambiental a partir das diversas percepções de apropriação, uso e significação do território pelos grupos sociais. Desse modo, o conflito tem origem quando pelo menos um dos grupos tem a "forma social de apropriação do meio que desenvolvem ameaçadas por impactos indesejáveis - transmitidos pelo solo, água, ar ou sistemas vivos - decorrentes do exercício das práticas de outros grupos" [...] $]^{4}$.

Já Libiszewski (1992, p. 3) apresenta um conceito de conflito ambiental atrelado à degradação ambiental. "Ele é uma interferência desestabilizante no equilíbrio do ecossistema, provocada pela atividade do homem, associando-a como causa do conflito". Barros e Espínola (2016) criticam esse conceito, pois a existência do conflito está apenas associada à degradação ambiental como causa, consequentemente, descarta a existência de outros fatores produtores do conflito. Ellingsen e Hauge (2001) associam conflito ambiental diretamente à escassez de recurso induzida pela demanda e oferta e à distribuição desigual dos recursos naturais.

Apresentado o conceito de conflito ambiental sob a perspectiva de diferentes autores, é necessário identificar as suas características. A primeira delas é a multiplicidade de partes e de instâncias de tomada de decisão. Os atores desses conflitos são constituídos por múltiplos grupos que, por sua vez, representam vários indivíduos e interesses diversos, bem como geram a polarização de instâncias de tomada de decisão. A segunda característica é a diferença no nível de

\footnotetext{
${ }^{4}$ Para Zhouri et.al (2015, p. 58), o conflito "eclode quando o sentido e a utilização de um espaço ambiental por um determinado grupo ocorrem em detrimento dos significados e usos que outros segmentos sociais possam fazer de seu território, para com isso, assegurar a reprodução do seu modo de vida".
} 
conhecimento e de gerenciamento de informação por partes desses diversos atores. Nem sempre estes conseguem pagar por estudos técnicos ou têm à disposição as ferramentas necessárias para entender esse tipo de informação, cuja linguagem é excessivamente técnica. A terceira é a diferença de recursos e de poder que poderá existir entre os atores, seja quando os grupos organizados se deparam com o Estado, que dispõe de poderes técnicos e legais, seja frente às empresas, detentoras do poder econômico. (BOREL et al, 1999; CEBOLA, 2012).

A quarta é a diversidade cultural de relacionamento dos grupos sociais com a natureza, que reflete nas diferentes concepções de uso e acesso aos recursos naturais e também no modo como o direito de propriedade é visto. A quinta é a existência de interesses não representados frente à ausência de um grupo organizado que se articule para a sua defesa. A sexta consiste no caráter transtemporal, que atinge a geração presente e futura, e transfronteiriço, pois ultrapassa as barreiras geográficas do local do dano, como o rompimento da barragem de Mariana-MG. A sétima é a necessidade de informações legais, sociais, econômicas e científicas para medir o impacto do conflito quanto as suas consequências atuais e futuras, assim como a relação custo beneficio que representa para a sociedade. A oitava é a incorporação pelo Direito da incerteza científica como um elemento para a tomada decisão em matéria ambiental, com fundamento no Princípio da Precaução ${ }^{5}$. Por último, a possibilidade de alteração das premissas iniciais das decisões ambientais para que elas possam ser adaptadas às consequências imprevistas, que são identificadas somente após a concretização da decisão ${ }^{6}$. (BLACKBURN; BRUCE, 1995).

Além das características, os atores desses conflitos são classificados em categorias. A primeira é denominada de receptor, que são as pessoas físicas ou jurídicas afetadas direta ou indiretamente pelos seus impactos ambientais. A segunda categoria é denominada de gerador, compreendida como o grupo que, por meio da ação e omissão, ocasiona um impacto ambiental. Já a terceira é denominada de regulador, pessoa jurídica ou grupo que tem a função de regular a gestão dos bens ambientais. A quarta é chamada de iniciador e inclui pessoas físicas e jurídicas que iniciam o conflito devido ao conhecimento do impacto ambiental, sendo possível que esta coincida com o receptor ${ }^{7}$. (SANTANDREU; GUDYNAS, 1998).

\footnotetext{
${ }^{5}$ A precaução é aplicada quando há o risco de degradação do meio ambiente, mesmo que o nexo causal não tenha sido ainda estabelecido, em razão dos danos ambientais serem de difícil reparação (MILARÉ, 2017).

${ }^{6}$ No mesmo sentido, Aguilar (1999) e Santander, Gudynas (1998).

7 "Considera-se impacto ambiental qualquer alteração das propriedades físicas, químicas e biológicas do meio ambiente, causada por qualquer forma de matéria ou energia resultante das atividades humanas que, direta ou indiretamente, afetam: I - a saúde, a segurança e o bem-estar da população; II - as atividades sociais e econômicas; III - a biota; IV - as condições estéticas e sanitárias do meio ambiente; V - a qualidade dos recursos
} 
O desenvolvimento de um conflito ambiental abrangem cinco etapas. A primeira delas é a cooperação, etapa na qual as partes, por meio do diálogo e de atitudes colaborativas, visam a buscar estratégias para superar o conflito. A segunda etapa é a indiferença percebida por uma das partes ou grupos aliados, pautada pela negligência para superar obstáculos. A terceira é a concorrência entre dois modelos de gestão ambiental que disputam espaço para fins de atingir reconhecimento e legitimidade. A quarta é a tensão crescente, pois as partes não conseguem perceber que suas diferenças podem ser superadas por meio do diálogo e da cooperação, caso em que as decisões são tomadas por aqueles que detêm o poder. A penúltima é o confronto de interesses, valores e opiniões sobre o conflito, o que interfere ou impede o alcance de um fim comum. A última etapa é a crise, momento em que o conflito é exteriorizado por meio de ações violentas, podendo ocorrer agressões entre as partes. (QUINTANA RAMÍREZ, s/d).

Destacam-se, também, as causas que ocasionam um conflito ambiental, pois estas influenciam na escolha do procedimento e das medidas ambientais adequadas a sua resolução. A primeira causa é o conflito devido à ausência de informações necessárias para a tomada de decisão, especialmente quando as partes envolvidas estão mal informadas ou quando está em discussão a interpretação em relação a estas informações. Para superar este tipo de conflito, é preciso fornecer informações adequadas e confiáveis para garantir a transparência. A segunda é o conflito por divergência de interesses, tais como dinheiro, tempo, percepção de confiança e honestidade. A superação desse conflito exige uma solução que atenda na mesma proporção os interesses de todas as partes quanto aos aspectos acima $\operatorname{ditos}^{8}$. A terceira são os conflitos por problemas estruturais, como é o caso do modelo de gestão entre as instituições do Estado e os indivíduos, além da escassez de recursos financeiros e humanos, as limitações geográficas e limitações de autoridade ${ }^{9}$. A última surge da existência de valores diferentes para avaliar os fatos ${ }^{10}$. Por fim, embora na maioria das

ambientais" (ARTIGO $1^{\circ}$ DA RESOLUÇÃO DO CONAMA № 1).

${ }^{8}$ Como exemplo, cita-se o conflito em torno da definição quanto ao uso e o gerenciamento de um parque num dado município. De um lado, um grupo de ambientalistas e moradores residentes em torno do parque defende que a sua administração deve ser de responsabilidade do Poder Público, para que o mesmo seja conservado. Por outro lado, a secretaria do Turismo do município defende que o parque deve ser conservado e administrado pelo setor privado, com a finalidade de impulsionar o turismo na região. (QUINTANA RAMIREZ, s/a ; MARTINEZ GONZALEz,1997).

${ }^{9} \mathrm{O}$ conflito gerado entre a população local, o Estado e as empresas privadas em decorrência da venda de uma Companhia Estadual prestadora de serviço público que envolve a exploração de elemento natural, tal como a água. (QUINTANA RAMIREZ, s/a ; MARTINEZ GONZALEZ,1997).

${ }^{10} \mathrm{Como}$ exemplo, cita-se o conflito entre os grupos indígenas e ambientalistas: de um lado, o Estado e outros ativistas, de outro lado, quanto à construção da Usina Hidrelétrica de Belo Monte no curso do Rio Xingu. No centro da discussão, estão o respeito à integridade cultural, os impactos ambientais e sociais desta atividade e o aumento da produção de energia no país. (QUINTANA RAMIREZ, s/a ; MARTINEZ GONZALEz,1997). 
vezes prevaleça uma das quatro causas apresentadas, os conflitos ambientais originam-se de várias delas. (QUINTANA RAMIREZ, s/d; MARTINEZ GONZALEZ, 1997).

A diversidade de conceitos explicita a dificuldade de ser estabelecida uma definição rígida no que se refere a sua causa e ao que deve ser considerado como conflito. Assim, opta-se pela não definição rígida do significado de conflito ambiental, ou seja, independentemente da sua causa geradora, a forma de interação estabelecida entre homem e meio ambiente e seus recursos naturais é o elemento central para a sua configuração. Por último, adotou-se o termo "conflito ambiental" ao invés de "conflito socioambiental", pois se enfatiza o aspecto ambiental e técnico e não aqueles ligados à ordem social, política e étnica, sem desconsiderar o fato de que a área ambiental se relaciona com outras Ciências ${ }^{11}$.

A partir do exposto, a existência de conflitos ambientais exige que o Direito pense em novas formas de resolvê-los, em especial por meio da via consensual. É preciso fortalecer as práticas em que o processo de tomada de decisão seja baseado no diálogo e na participação. Por isso, é importante iniciar as discussões no próximo item sobre a necessidade de o Ministério Público brasileiro consolidar uma postura resolutiva na área ambiental. Para corroborar essa afirmação, serão apresentados os dados da pesquisa empírica acerca das Ações Civis Públicas ambientais junto ao Tribunal de Justiça de São Paulo no ano de 2017.

\section{EXPLICAÇÃO METODOLÓGICA}

Desta forma, inicialmente, será explicado o procedimento metodológico utilizado para a coleta de dados e, posteriormente, será feita a análise destas informações. Trata-se, assim, quanto ao método ${ }^{12}$ de uma pesquisa com abordagem predominante qualitativa, devido ao recorte restrito da amostra ${ }^{13}$, embora este expresse uma dimensão da representação do objeto pesquisado. Optouse pela utilização de fontes de dados primários, compreendidos como "os dados que o próprio

\footnotetext{
${ }^{11}$ Conflitos socioambientais "actuales son mucho más que meras disputas por la propiedad de un recurso. En ellos se encuentran enfrentadas cosmovisiones ambientales y de vida. Por un lado, el medio ambiente es visto como un recurso económico, o sistema de recursos naturales; y por otro lado, el medio ambiente se hace equivaler a "espacios o escenarios de vida". El problema radica en que el encuentro entre estas dos perspectivas se da bajo un contexto o lógica de dominación. (QUINTANA RAMÍREZ, s/d, p. 7). (Os atuais conflitos socioambientais são muito mais do que meras disputas sobre a propriedade de um recurso. Eles são confrontados com cosmovisões ambientais e da vida. Por um lado, o meio ambiente é visto como um recurso econômico ou sistema de recursos naturais; e por outro lado, o ambiente é equivalente a "espaços ou cenários de vida". O problema reside no fato de que o encontro entre essas duas perspectivas ocorre sob um contexto ou lógica de dominação).

${ }^{12}$ Método é a "forma de abordagem, de observação e produção de conhecimento". (LIMA, 2016, p. 54).

13 "A pesquisa qualitativa trabalha com o universo de significados, motivos, aspirações, crenças, valores e atitudes, o que corresponde a um espaço mais profundo das relações, dos processos e dos fenômenos que não podem ser reduzidos à operacionalização de variáveis". (MINAYO, 2008, p. 14).
} 
pesquisador delineou para sua coleta a partir das suas próprias questões de pesquisa". (LIMA, 2016, p.16). Nesse tipo de coleta, o pesquisador tem liberdade para desenvolver suas questões, organizar o questionário e definir a amostra representativa da população, de acordo com o tema ser pesquisado. Esses dados foram organizados em gráficos e tabelas para fins de facilitar a sua compreensão. (LIMA, 2016).

Uma das etapas para o desenho da pesquisa é a definição do elemento ou unidade de análise, em outras palavras, o que o pesquisador pretende pesquisar. Uma vez definido como unidade de análise a ACP ambiental, é preciso selecionar as variáveis a serem pesquisadas: "tratase de um conceito empírico ou teórico que pode assumir diversos valores e para a qual, mediante observações, é possível especificar o valor que ela assume no problema específico a ser investigado". (LIMA, 2016, p.20). Nesse sentido, foram utilizadas as seguintes variáveis:

$\checkmark$ Em relação à duração dos processos, a data de distribuição da ACP e a data de remessa ao Tribunal de Justiça, para identificar a média de duração da resolução destas, Acerca dos legitimados passivos da ACP, utilizaram-se empresas, pessoas físicas e órgãos /instituições do governo para identificar as categorias de agentes envolvidos e as ocorrências mais frequentes;

$\checkmark$ Sobre as matérias envolvidas nas ACPs, os assuntos selecionados foram "flora", "fauna", "área de preservação permanente" com a finalidade de verificar quais destas ocorrem com mais frequência;

Quanto aos resultados das decisões de $1^{\circ}$ instância, há sentenças julgadas procedentes, improcedentes ou parcialmente procedentes; e

Quanto às decisões de $1^{\circ}$ instância objeto de recurso, há sentenças confirmadas, reformadas total ou parcialmente, anuladas, desistência ou acordos para identificar o índice de reforma de sentença,bem como compará-las com a resolução negociada;

$\checkmark \quad$ Quanto aos legitimados para a propositura da ACP, os entes arrolados no artigo $5^{\circ}$ da LACP, para verificar se o Ministério Público, entre os legitimados a agir em juízo, é aquele que tem posição mais destacada;

Como fontes da análise foram utilizadas as Ações Civis Públicas Ambientais, julgadas entre 10 de janeiro de 2017 e 30 de novembro de 2017, pela Primeira Câmara e Segunda Câmara reservada ao meio ambiente do Tribunal de Justiça do Estado de São Paulo. Para tanto, foi realizada pesquisa jurisprudencial no site do Tribunal de Justiça de São Paulo, no link Jurisprudência-consulta completa, ementa Ação civil Pública Ambiental, órgão julgador Primeira Câmara e Segunda Câmara reservada ao meio ambiente, tipo de publicação acórdão, data de julgamento entre 10 de janeiro 
de 2017 e 30 de novembro de 2017. Como forma de delimitar a busca de ACPs, foram selecionados os temas acima arrolados. Da aplicação desses critérios, resultaram 56 ACPs, tendo sido excluídas 16 por se tratarem de Agravo de Instrumento e Embargos de Declaração, totalizando uma amostra de 40 ACPs ambientais pesquisadas ${ }^{14}$.

Embora a pesquisadora tivesse a pretensão de um levantamento mais amplo, optou-se pelo recolhimento de informações das ACPs junto ao Tribunal de Justiça em função de dois motivos. $O$ primeiro motivo consistiu no fato do TJ/SP dispor de duas Câmaras Reservadas ao julgamento de matéria sobre o meio ambiente. $O$ segundo consistiu no tempo reduzido para a realização da pesquisa de campo se comparado ao prazo final de entrega da tese.

Destaca-se que um dos vieses da pesquisa é o cotejo dos resultados desta pesquisa com os dados já existentes, tendo a finalidade de verificar se há uma aproximação ou não entre estes. Tal comparação foi realizada com os dados provenientes da última edição do relatório Justiça em Números (CNJ, 2017), Justiça Pesquisa em Número-Ações Coletivas no Brasil e com o banco de dados sobre a resolução negociada de conflitos ambientais, organizado pelo Centro de pesquisa em Direito e Meio Ambiente (CDMA) da Escola de Direito da Fundação Getulio Vargas (FGV) em parceria com o MP/MG.

\section{ANÁlISE DOS RESULTADOS DA PESQUISA EMPÍRICA SOBRE AS AÇÕES CIVIS PÚBLICAS AMBIENTAIS AJUIZADAS NO TRUBUNAL DE JUSTIÇA DE SÃO PAULO}

Discorrido sobre o procedimento metodológico utilizado nesta pesquisa, nas páginas que seguem serão apresentados os resultados das análises realizadas por meio da leitura dos 40 processos. Inicia-se pela apresentação dos dados referentes aos legitimados para a propositura da ACP. Como resultado, ilustrado pelo gráfico abaixo, observou-se que o órgão ministerial é o responsável pela propositura da ACP em $72 \%$ da amostra pesquisada. Em seguida, com 10\%m aparecem os entes da Federação, sendo três delas propostas pelo Estado de SP e uma delas pelo Município de São Paulo. A Fazenda Pública, enquadrada na categoria de autarquia, aparece com $5 \%$ ou duas ACPs ajuizadas. Com atuação bem menos expressiva, aponta-se a Defensoria Pública, responsável pela propositura de apenas uma ACP e também as associações, que ajuizaram $5 \%$ ou duas ACPs.

\footnotetext{
${ }^{14}$ Optou-se, assim, quanto ao processo de amostragem, por uma amostra não probabilística, compreendida como "aquelas nas quais não são sabemos, de antemão, as chances que cada elemento da população tem de se selecionado para amostra-independentemente de ter chances iguais ou não". (LIMA, 2016, p.37).
} 
Gráfico 01-Legitimados ativos para a propositura da Ação Civil Pública

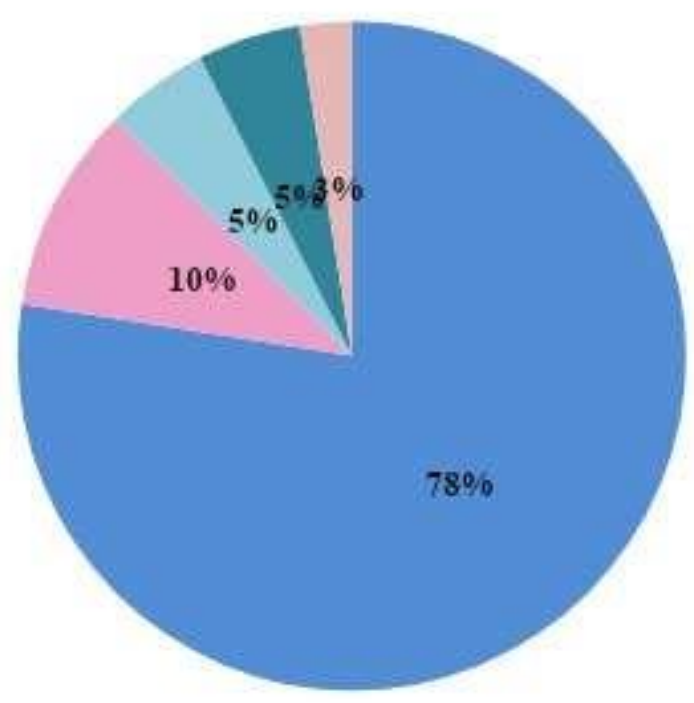

Ministério Público:

União,Estados,Distrito Federal e os Municipios:

Autarquia, empresa pública,

fundação ou sociedade de economia mista

Associações

Defensoria Pública

Nota: Elaborado pela Autora (2018).

Assim, os dados apresentados confirmam a hipótese levantada inicialmente de que o MP é o protagonista na tutela ambiental embora a LACP tenha estendido essa legitimidade a cinco agentes distintos, que podem atuar em conjunto ou separadamente. Além disso, há baixa propositura da ACP por parte das associações como estratégia e instrumento de proteção do meio ambiente. Em síntese, a ACP permanece sob a égide dos atores estatais, mais do que a da própria sociedade civil a quem deveria ter aberto espaço. 
No mesmo sentido, os dados apresentados pela $2^{\circ}$ edição da Série Justiça Pesquisa: Ações coletivas no Brasil reafirma o protagonismo do MP na tutela coletiva. Trata-se de construção de um banco de dados com 52 mil ações coletivas coletadas no site dos Tribunais Superiores, Tribunais Regionais Federais e de seis Tribunais Estaduais ${ }^{15}$, além de aplicação de um survey com juízes de primeira instância nos TRFs e TJs. A finalidade foi verificar o que dizem as ações coletivas existentes no país e as principais dificuldades enfrentadas em seu julgamento bem como a percepção dos operadores do direito sobre a tutela coletiva.

Dos 142 questionários respondidos pelos juízes estaduais e federais das varas que possuem competência para julgar ações coletivas, $94,4 \%$ deles afirmaram que a legitimidade do MP para a defesa de interesses coletivos é alta, enquanto o percentual cai para 55,3\% quando se trata de associações civis ${ }^{16}$. Do total das 677 ações coletivas analisadas, o MP Estadual está presente em quase metade das decisões ou em mais da metade delas para o STF, STJ e TJ/GO. (CNJ, 2018).

Entre os fatores apontados para o predomínio do MP na área de defesa dos direitos difusos e coletivos, de acordo com a percepção dos magistrados, está a maior expertise do órgão ministerial no manejo das ACPs associada às melhores condições institucionais, como órgãos especializados no âmbito da instituição e recursos humanos. Outro fator apontado é o fato de o MP contar com o inquérito civil e o TAC e seus membros disporem de estabilidade no cargo e independência funcional. Segundo eles, a LACP contribuiu para fortalecer a atuação do órgão ministerial na área de tutela coletiva, mais do que as organizações da sociedade civil. No que tange à fase de adjudicação, os juízes consideraram as ações coletivas ajuizadas pelo MP melhor fundamentadas do que aquelas movidas pelas associações. (CNJ, 2018).

A pesquisa do CNJ mostrou que o desestímulo a demandas coletivas ambientais e o seu êxito está diretamente relacionada à capacidade do demandante de fazer provas técnicas e materiais do dano ambiental. Outro fator prejudicial é o critério utilizado para a definição da competência de foro, o local do dano, visto que "este fato é de difícil determinação a depender do âmbito e dimensão do dano ambiental verificado ou potencial”. (CNJ, 2018, p. 52).

Entre os demais legitimados para a propositura das ações coletivas, observou-se um baixo percentual de participação das Defensorias Públicas, Estaduais ou da União, em todos os Tribunais,

\footnotetext{
${ }^{15}$ Alagoas, Ceará, Goiás, Pará, São Paulo e Rio Grande do Sul.

${ }^{16}$ Dos 337 questionários, 142 foram respondidos pelos magistrados, outros 19 tiveram que ser substituídos por diversos motivos e 176 permaneciam em aberto quando do fechamento do survey para a elaboração do presente relatório.
} 
o que pode ser explicado pela recente inclusão deste órgão no rol dos legitimados em processos coletivos, além de ter sido objeto de ADIN proposta pelo MP junto ao STF, julgada improcedente na data de 07 de maio de 2015, sanando qualquer dúvida acerca da atribuição da Defensoria Pública na defesa dos direitos coletivos ${ }^{17}$. (CNJ, 2018).

Quanto às ações coletivas ambientais, a maioria delas são ACPs propostas pelo MP Estadual (62\%). O MPF atua de forma preponderante em conjunto com outros atores federais responsáveis pela fiscalização ambiental, como o IBAMA, Município e União, em 19\% dos casos pesquisados. 0 gráfico abaixo ilustra esses dados:

Gráfico 02-Demandantes nas ações coletivas ambientais

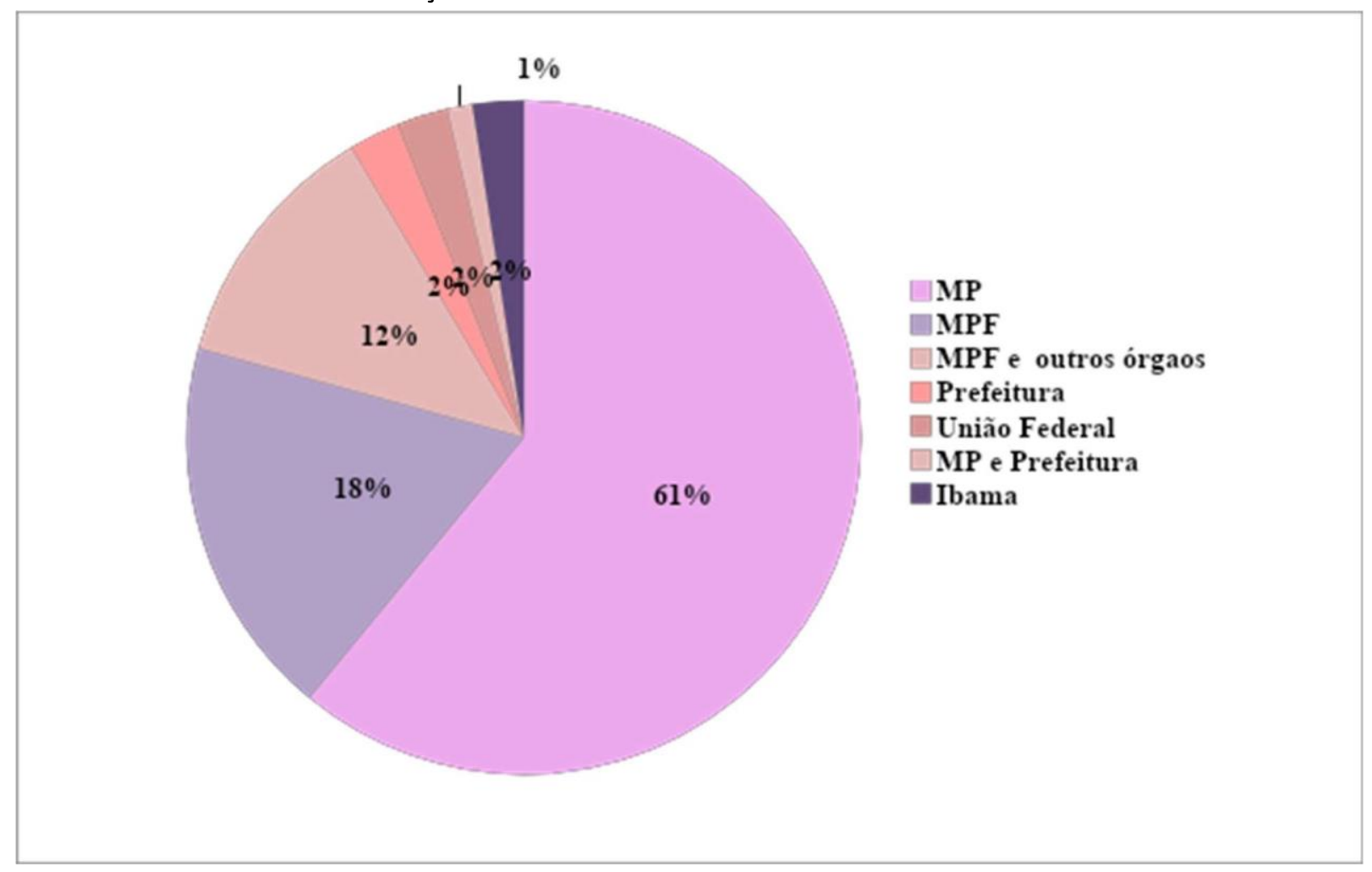

Nota: Elaborado pela Autora (2018).

\footnotetext{
${ }^{17}$ Sua legitimidade ativa foi reconhecida primeiramente no artigo $5^{\circ}$, II, da Lei da Ação Civil Pública, com redação dada pela Lei $n^{\circ} 11.448 / 2007$, e depois incluída entre suas funções institucionais, no artigo $4^{\circ}$, VII, da Lei Complementar $n^{\circ} 80 / 1994$, alterada pela Lei Complementar $n^{\circ} 132 / 2009$. Igualmente, a Emenda Constitucional $n^{\circ} 80 / 2014$ incumbiu a Defensoria Pública "da defesa, em todos os graus, judicial e extrajudicial, dos direitos individuais e coletivos, de forma integral e gratuita, aos necessitados" (art. 134, caput, da CF/88, grifo da autora).
} 
O segundo dado levantado consistiu nos legitimados passivos das ACPs ambientais, situação em que foram utilizadas as seguintes categorias: empresas, pessoas físicas e órgãos/instituições do governo. Nesse caso, a hipótese inicial levantada de que a ACPs teriam como legitimado empresas na sua maioria não se confirmou, já que, em $60 \%$ da amostra pesquisada, o legitimado passivo enquadrou-se na categoria pessoa física. Esse número significativo de pessoas físicas no polo passivo das ACPs pode ser justificado em razão do seu objeto, que é a Área de Preservação Permanente ( $53 \%$ da amostra), isto é, trata-se de pessoas físicas proprietárias.

Do total da amostra pesquisada, a categoria empresas aparece em $22 \%$ da amostra pesquisada. Como exemplo dessa ocorrência, apareceram as empresas de energia, remoção de entulho, agropecuárias e os empreendimentos imobiliários. De forma menos expressiva, a atuação omissiva dos órgãos ou instituições do governo em relação à proteção das Áreas de Preservação Permanente correspondeu a $15 \%$ ou 6 ACPs.

Gráfico 03- Demandados nas ações coletivas ambientais

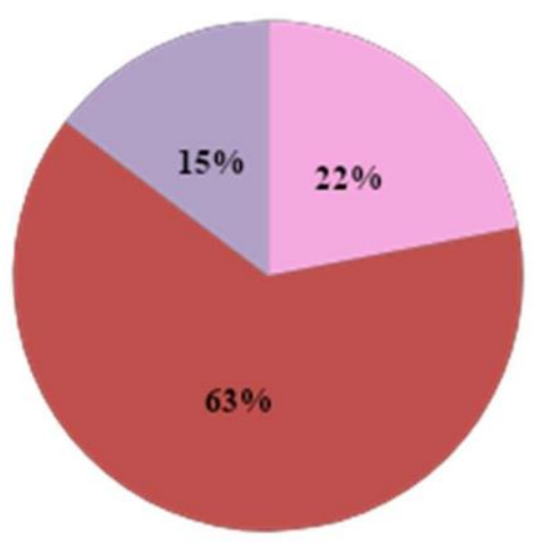

Empresas

Pessoas Fisicas

Órgãos ou isntituições do

governo

Nota: Elaborado pela Autora (2018).

Diversamente, a pesquisa realizada pelo Centro de Direito e Meio ambiente (CDMA) da Escola de Direito FGV/RJ em parceria com o Núcleo de Resolução Consensual de Conflitos do MP/MG constatou que, dos 40 procedimentos instaurados, $74 \%$ deles tinha como principal agente envolvido as empresas, seguido dos órgãos e instituições do governo, em $22 \%$ da amostra pesquisada. 
O terceiro dado pesquisado buscou identificar as matérias envolvidas nas ACPs, entre aquelas selecionadas de forma prévia pela pesquisadora, que são Fauna ${ }^{18}$, Flora ${ }^{19}$ e Área de Preservação Permanente ${ }^{20}$. 0 gráfico abaixo indica que $53 \%$ das ACPs tinham como matéria danos em Área de Preservação Permanente, seguida de danos à Flora, com 42\%. De forma inexpressiva, aparece com $5 \%$ o tema fauna como objeto da ACP.

Gráfico 04-Matérias envolvidas nas Ações Civis Públicas ambientais

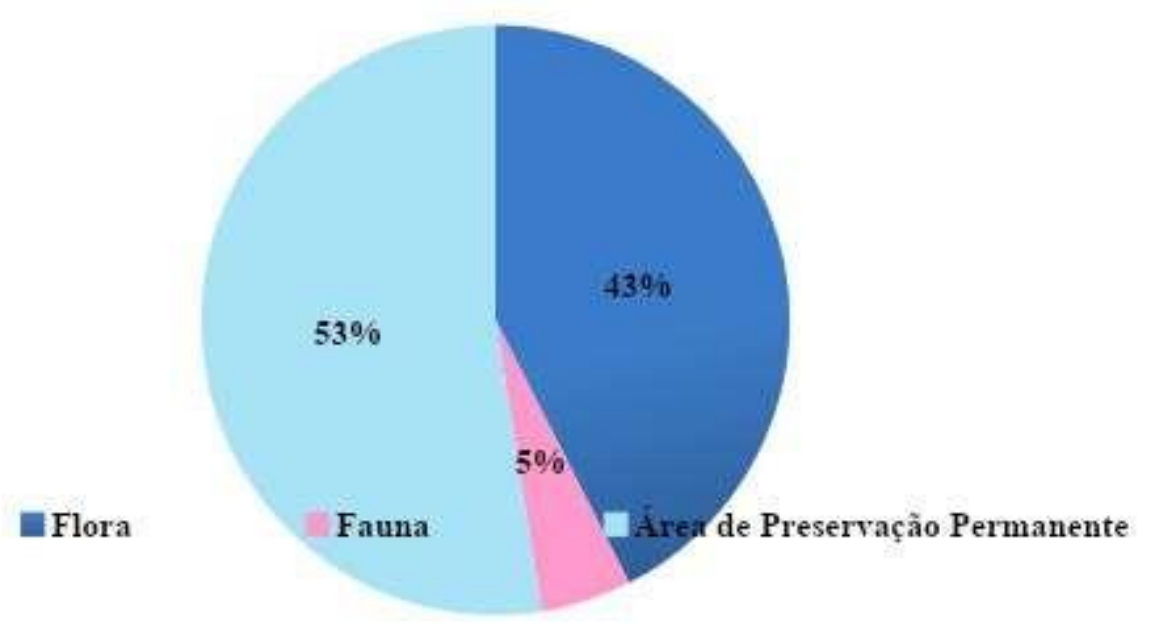

Nota: Elaborado pela Autora (2018).

Comparativamente, a pesquisa do CNJ (2018) mostrou que das 82 ações coletivas ambientais julgadas e distribuídas entre TJSP, TRF2, TRF3 e TRF4, 60\% delas tiveram como objeto danos em Área de Preservação Permanente e danos em Reserva Legal, com 35\% da amostra pesquisada. Em 10\% das ACPs, classificadas como "outros assuntos", as matérias em discussão eram a criação de unidade de conservação, recuperação de dano ambiental em área de depósito

\footnotetext{
${ }^{18}$ Fauna: “Conjunto de animais que vivem numa determinada região, ambiente ou período geológico", sendo que a noção vulgar se refere ao "conjunto dos animais que habitam o planeta na atualidade ou que nele viveram em épocas anteriores" (MILARÉ, 2017, p.171).

${ }^{19}$ Flora: "É entendida como a totalidade das espécies que compreende a vegetação de uma determinada região, sem qualquer expressão de importância individual dos elementos que a compõem" (MILARÉ, 2017, p.161).

${ }^{20}$ Artigo, $3^{\circ}$, II, da Lei no 12.651, de 25 de maio de 2012: “Área de Preservação Permanente: Área protegida, coberta ou não por vegetação nativa, com a função ambiental de preservar os recursos hídricos, a paisagem, a estabilidade geológica e a biodiversidade, facilitar o fluxo gênico de fauna e flora, proteger o solo e assegurar o bem-estar das populações humanas".
} 
de lixo, demolição e dever de reparação do dano, recuperação de dano ambiental em área de exploração mineral, loteamento clandestino e ocupação de área de amortecimento.

O quarto dado pesquisado revela que $52 \%$ da ACPs forma julgadas procedentes em primeira instância, representando em termos absolutos 21 ACPs, ou parcialmente procedentes com $40 \%$ da amostra. Por último, aparece a improcedência das ACPs, correspondendo apenas a $5 \%$ da amostra pesquisada, e uma ACP extinta sem julgamento de mérito nos termos do artigo 485 do CPC.

Apesar de a análise desta variável ter evidenciado que boa parte das ACPs foi julgada procedente ou parcialmente procedente, o índice de recurso é alto, como será analisado logo a seguir. Além disso, nem sempre uma vitória judicial significa a resolução do conflito devido à dificuldade de acompanhamento e fiscalização do cumprimento das sentenças. Nesse sentido, $95 \%$ dos magistrados entrevistados consideraram a estrutura existente como inadequada em alguma medida para executar as decisões judiciais em ação coletiva. (CNJ, 2018).

Gráfico 05-Decisões de $1^{\circ}$ instância

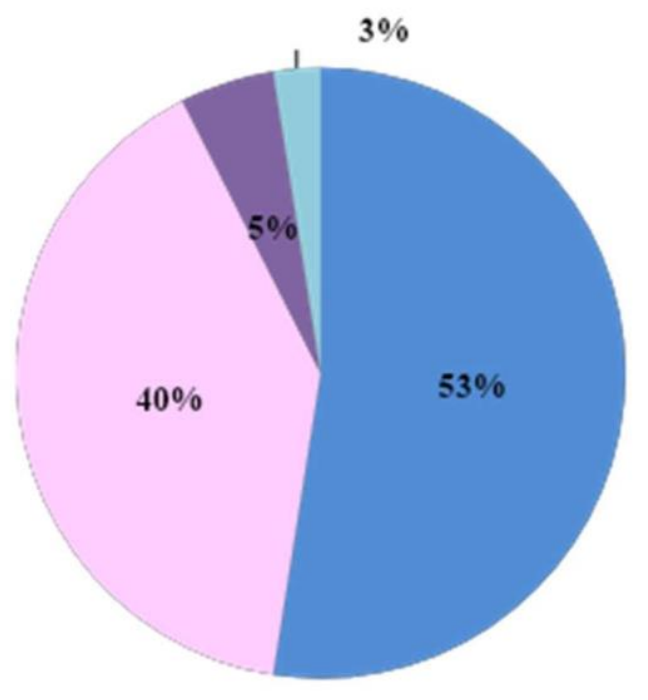

Procedente

Parcialmente Procedente

Improcedente

Outros

Nota: Elaborado pela Autora (2018).

Quanto à abrangência espacial da coisa julgada, 92,7\% dos magistrados responderam que as ações coletivas podem ser executadas em outros Estados que não aquele em que foram decididas, sendo que $63 \%$ deles frisaram que isso pode ocorrer quando o objeto da sentença tiver alcance regional ou nacional, enquanto que $29,7 \%$ não fizeram esta restrição. Somente $7,2 \%$ dos 
magistrados entenderam que as sentenças coletivas podem ser executadas no Estado em que foram proferidas.

O quinto dado referiu-se ao índice de reformas de sentença de $1^{\circ}$ instância. Conforme disposto no gráfico abaixo, $56 \%$ das decisões de primeira instância objeto de apelação foram confirmadas pelo TJ/SP. As decisões reformadas parcialmente representaram $30 \%$ da amostra pesquisa, enquanto que apenas $14 \%$ delas foram reformadas na integralidade ${ }^{21}$. Não houve sentença anulada, acordo ou desistências.

Gráfico 06-Índice de Reforma de sentença

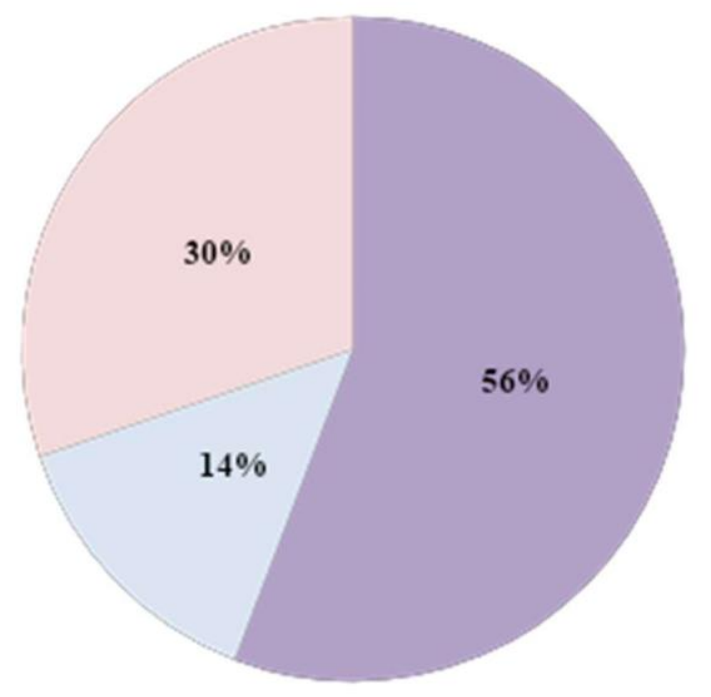

Sentenças Confirmadas Sentenas reformadas totalmente Sentenças Reformadas parcialmente

Nota: Elaborado pela Autora (2018).

Como pode ser visualizado no gráfico a seguir, $74 \%$ (ou 32) das apelações interpostas no $\mathrm{TJ} / \mathrm{SP}$ contra as decisões de $1^{\circ}$ instância tiveram como legitimado ativo os demandados, o que pode ser justificado pelo fato de a maioria das ACPs terem sido julgadas procedentes ou parcialmente procedentes em favor dos demandantes na $1^{\circ}$ instância, no caso o MP. Apenas $26 \%$ das apelações foram interpostas pelos demandantes ${ }^{22}$.

\footnotetext{
${ }^{21}$ Justificam-se,43 amostras, neste caso, visto que, nas ACPs $n^{\circ} 0054788-76.2012 .8 .26 .0346, n^{\circ} .1005147-$ 20.2014.8.26.0577 e $\mathrm{n}^{\circ}$ 0001820-50.2015.8.26.0480, autor e réu interpuseram recurso. Todas as 40 ACPs foram objeto de recurso.

22 Justificam-se, 43 amostras, neste caso, visto quem nas ACPs n'0054788-76.2012.8.26.0346, $n^{\circ}$. 100514720.2014.8.26.0577 e n 0001820-50.2015.8.26.0480, autor e réu interpuseram recurso.
} 
Gráfico 07- Percentual de apelação interposta pelos demandados e demandantes

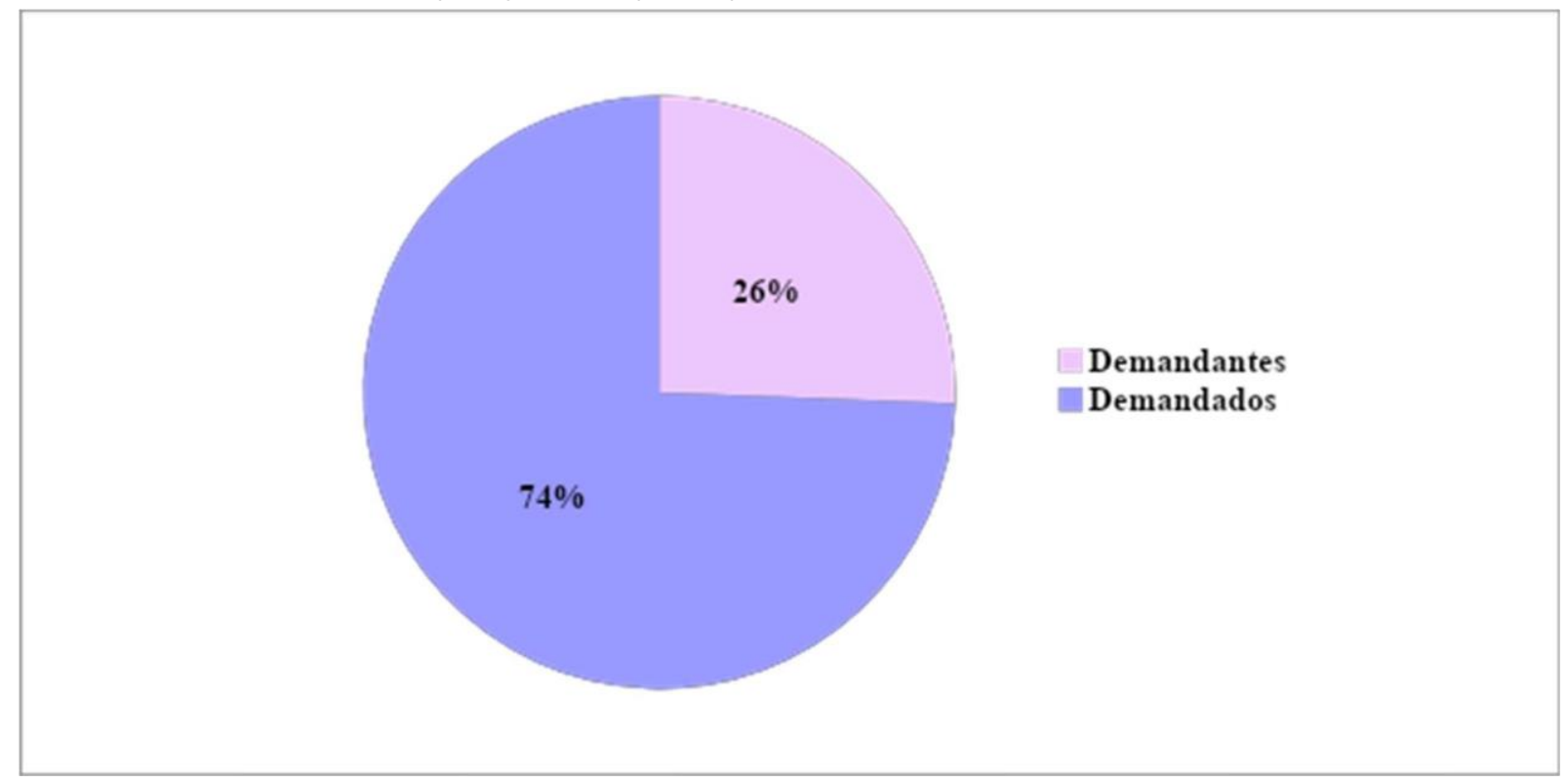

Nota: Elaborado pela Autora (2018).

Para detalhar a análise desses resultados, o gráfico abaixo mostra que, das 32 apelações interpostas pelos demandados, apenas $12 \%$ foram julgadas providas integralmente. Na sua maioria, as ACPs foram julgadas desprovidas (50\%) ou providas parcialmente (38\%). Esses dados revelaram que boa parte das sentenças proferidas pelo juízo de $1^{\circ}$ grau foi mantida integral ou parcialmente pelo Tribunal. 


\section{Gráfico 08- Resultado dos recursos interpostos pelos demandantes}

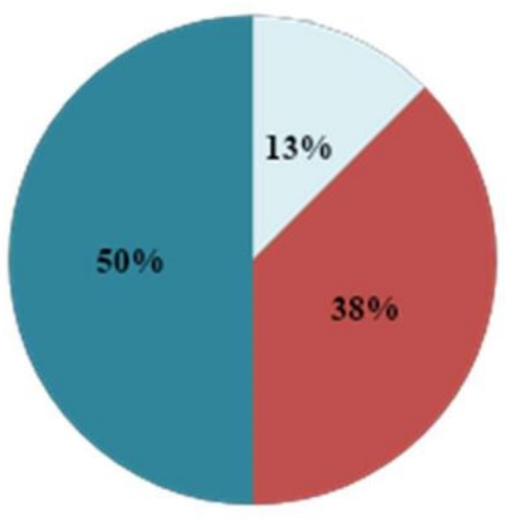

Favorável ao demandando

Parcialmente favorável ao

demandado

Desfavoravel ao demandado

Nota: Elaborado pela Autora (2018).

Essa tendência de confirmação das sentenças proferidas em $1^{\circ}$ grau igualmente foi verificada em relação aos recursos interpostos pelos demandantes. Em $73 \%$ das apelações interpostas, o resultado foi desfavorável e, apenas em $27 \%$ da amostra pesquisada, a apelação foi julgada total ou parcialmente favorável ao demandante.

Gráfico 09- Resultado dos recursos interpostos pelos demandantes

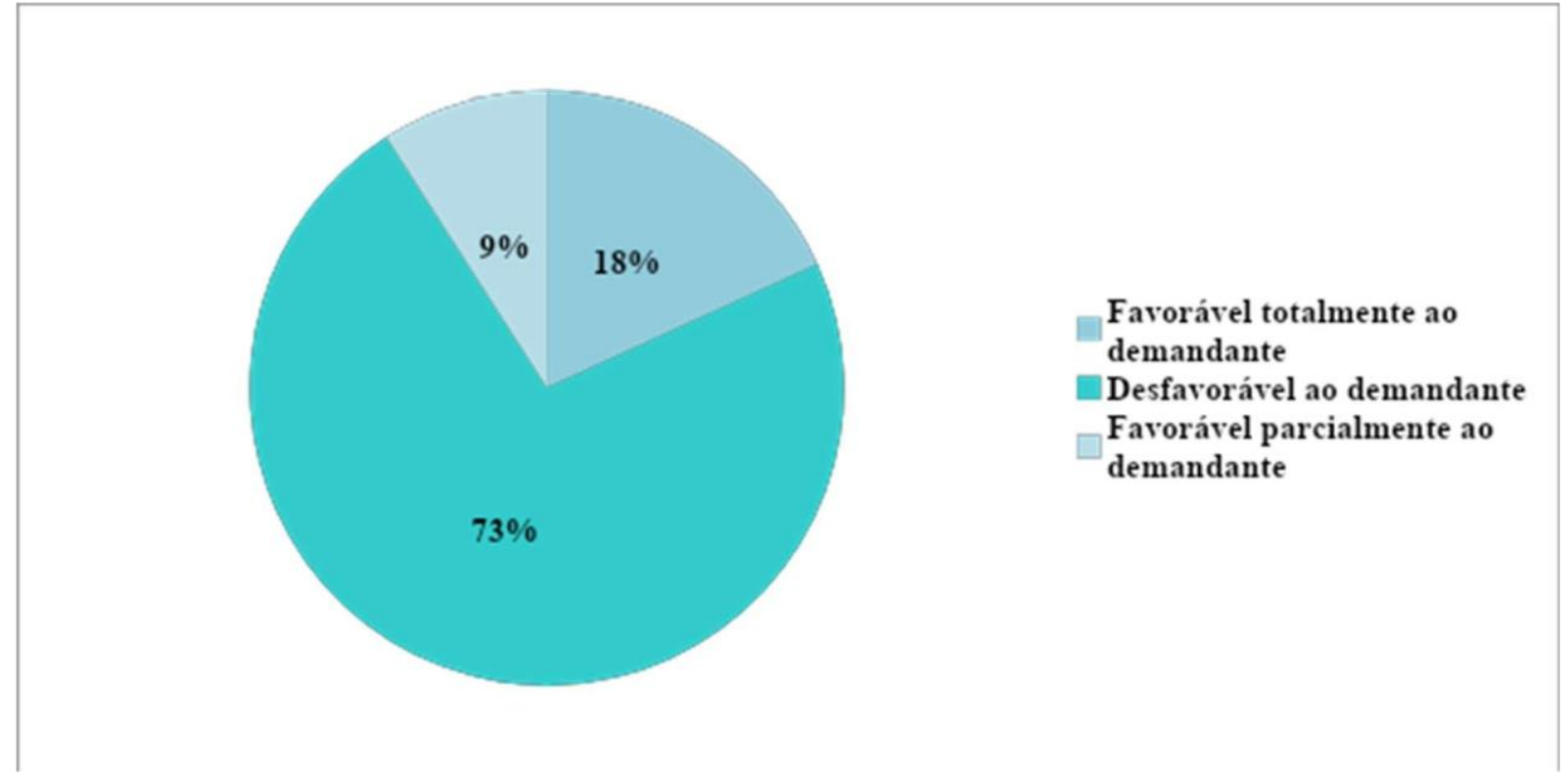

Nota: Elaborado pela Autora (2018). 
A pesquisa sobre as ações coletivas apontou que a maioria das decisões favoráveis ao órgão ministerial na esfera estadual é revertida parcialmente pelos indivíduos e empresas em sede apelação, em especial quando o dano ambiental não se mostra grave ou ocorre em área urbana consolidada. Já os TRFs apresentam uma tendência de decidir em favor do MP, com 13 apelações consideradas providas contra três julgadas favoráveis às empresas e indivíduos. Esse último dado sustenta a hipótese de que os juízes federais têm mais familiaridade com as normas ambientais que os juízes e tribunais estaduais, bem como que a atuação do MP e dos órgãos federais de proteção ambiental na propositura das demandas pode levar à produção de provas mais contundentes. (CNJ, 2018).

Por fim, o último item analisado refere-se ao tempo de duração de tramitação das ACPs em $1^{\circ}$ grau, elemento importante para as reflexões sobre a resolução negociada de conflitos na área ambiental. O cálculo da duração média de tramitação das ACPs levou em conta a data de distribuição do processo como termo inicial e a data de remessa ao Tribunal como termo final, o que levou a pesquisadora a identificar o número de anos para depois transformá-lo em meses.

a média de tramitação das ACPs é de 49,9 meses, ao passo que os procedimentos que tramitam no NUCAM são resolvidos em 9,6 meses. A hipótese de morosidade do Poder Judiciário no julgamento dos processos também é confirmada pelos dados contidos no Relatório Justiça em Números - 2017, organizado pelo Conselho Nacional de Justiça. O tempo médio de tramitação dos processos até a sentença no TJ/SP é de 44 meses, número próximo daquele pesquisado em relação às Ações Civis Públicas Ambientais.

As principais categorias de problemas apontadas pelos juízes nas ações coletivas são sintetizadas abaixo (CNJ, 2018):

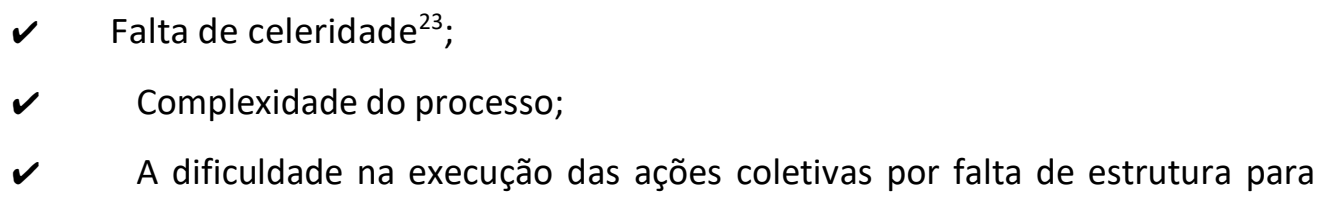
acompanhar o cumprimento da sentença ou acordo;
$\checkmark \quad$ O predomínio da cultura de ação individual sobre uma cultura de ação coletiva;
$\checkmark \quad$ Ausência de estrutura e excesso de trabalho;

\footnotetext{
${ }^{23}$ Esta morosidade do Poder Judiciário decorre de quatro fatores. O primeiro é o formalismo do procedimento. O segundo é a multiplicidade de réus, o que resulta no excesso de prazos. O terceiro consiste na ausência de um procedimento unificado para as ações coletivas. O último fator apontado é a complexidade da instrução e dos tipos de pedidos (CNJ, 2018).
} 
$\checkmark \quad$ O custo da prova pericial técnica;

$\checkmark \quad$ O despreparo ou a falta de cooperação das partes, inclusive do MP e DP;

$\checkmark \quad$ A multiplicidade de processos sobre o mesmo tema;

$\checkmark \quad$ Dificuldades na produção de provas e má qualidade dos inquéritos civis;

$\checkmark \quad$ Falta de publicidade sobre as ações existentes, em curso e julgadas;

$\checkmark \quad$ O uso político das ações coletivas; e

$\checkmark \quad$ O conhecimento dos juízes e dos servidores sobre este tema não é satisfatório ${ }^{24}$.

Em síntese, os dados apresentados sobre as ACPs, corroborados com os dados das pesquisas realizadas pelo CNJ e FVG/RJ, apontam que o órgão ministerial é o protagonista na tutela ambiental, ao passo que a participação das associações e da Defensoria Pública como legitimado ativo da ACP é inexpressiva. Esses fatos indicam que o sistema de tutela coletiva permanece sob a égide dos atores estatais e não conseguiu consolidar a ampliação do acesso à justiça no que se refere à participação da sociedade civil.

Na maioria das amostras pesquisadas, a parte que teve o seu pedido julgado parcial ou totalmente improcedente interpõe recurso, o que atrasa o início do cumprimento da sentença. Sob o aspecto temporal, a demora na tramitação das ACPs em matéria ambiental é negativa porque pode comprometer a reparação dos danos ambientais. Esta ausência de celeridade é agravada pela falha na fiscalização do cumprimento das sentenças ou acordos, o que torna as medidas de prevenção ou reparação estabelecidas pelo juiz inócuas.

Por derradeiro, os dados apontam a necessidade de o Direito pensar em outras formas de resolução de conflitos ambientais, além daquela realizada pela via judicial. Neste sentido, boa parte dos promotores de justiça entrevistada pelo CNJ concordou que a solução negociada, anteriormente à judicialização, é a melhor alternativa para a resolução de conflitos coletivos. Em suma, é preciso somar esforços para aperfeiçoar o direito processual coletivo brasileiro e estimular os mecanismos consensuais de resolução de conflitos ambientais, lançando mão da mediação ${ }^{25}$.

Desta forma, o próximo item dedica-se a discorrer sobre o modelo de atuação do órgão ministerial na área ambiental, em especial a consolidação do perfil resolutivo como forma de contribuir para a consolidação da terceira onda de acesso à justiça.

\footnotetext{
${ }^{24}$ Nesse sentido, esses dados apontam para a necessidade de uma política pública permanente de incentivo e aperfeiçoamento dos magistrados e servidores quanto à seara dos direitos coletivos e instrumentos processuais para tutelar estes direitos.

${ }^{25}$ Serão abordadas em item próprio as vantagens da mediação em relação ao processo judicial e o TAC.
} 


\section{POR UM NOVO MODELO DE ATUAÇÃO DO MINISTÉRIO PÚBLICO NA ÁREA AMBIENTAL: ENTRE OS PERFIS DEMANDISTA E RESOLUTIVO}

O perfil constitucional do Ministério Público está consagrado no artigo 127 , caput, da Constituição, que o define como instituição permanente e essencial à função jurisdicional do Estado, encarregado da proteção da ordem jurídica e democrática, bem como dos interesses sociais e individuais indisponíveis, entre os quais se inclui a proteção do meio ambiente em nome da sociedade. É também considerada uma instituição pública independente, que não pertence ao Poder Judiciário tampouco aos Poderes Executivo, Legislativo ou ao Tribunal de Contas, pois a Constituição conferiu-Ihe autonomia administrativa, orçamentária e funcional, nos termos do seu artigo $127, \S 2^{26}$.

Quanto à natureza institucional do Ministério Público, a concepção que melhor explica a sua postura institucional é aquela que o desloca da sociedade política, como órgão repressor do Estado, para a sociedade civil, como órgão defensor da sociedade. Primeiro, porque o MP assumiu um compromisso com a sociedade no transcorrer de sua evolução histórica. Segundo, porque a vocação da instituição está voltada para a defesa da democracia e das instituições democráticas. Terceiro, em razão da autogestão administrativa, orçamentária e funcional conferida ao MP pela Constituição. (ALMEIDA, 2013).

Na área ambiental, a posição de destaque do MP é materializada no exercício de sua função constitucional de provocar o exercício da jurisdição na defesa do meio ambiente, por meio da ACP, da titularidade exclusiva para a instauração do inquérito civil e da legitimidade para propor ação de responsabilidade civil e criminal, por danos causados ao meio ambiente. Em síntese, o órgão ministerial atua na esfera judicial como órgão da sociedade e defensor do povo, representando na via judicial os titulares do direito ao meio ambiente ecologicamente equilibrado ${ }^{27}$. (MIRRA, 2011).

Nesse ponto, é preciso ressaltar que o protagonismo do MP durante a segunda onda de acesso à justiça é contrastado pela sua atuação discreta no processo de afirmação da terceira onda, direcionada para a efetivação dos direitos em tempo razoável, a baixo custo e aberto à participação

\footnotetext{
${ }^{26}$ Corrobora com este posicionamento o fato de o MP ter sido inserido no Título IV "Da organização dos Poderes", no Capítulo "Das Funções Essenciais da Justiça", porém em seção própria, separado dos demais poderes do Estado. $E$, ainda, conferiu-lhe garantias funcionais aos membros do órgão ministerial para o exercício de suas funções, previstas no artigo $128, \$ 5^{\circ}$, inciso I, alienas " $a$ ", " $b$ " e " $c$ ", e traçou os seus princípios institucionais, de acordo com o artigo 127,\$1 ${ }^{\circ}$ da Constituição da República. (GOULART, 1998; ALMEIDA, 2013).

${ }^{27}$ Além de ser o legitimado para a propositura das ações coletivas ambientais, no direito brasileiro, o Ministério Público intervém como fiscal da ordem jurídica (custos legis), ou seja, ele é sempre parte no processo,seja como autor da demanda, seja como interveniente na condição de custos legis, comprometido com a tutela da qualidade ambiental. (MIRRA, 2011).
} 
das partes, vale dizer, mais voltada para o resultado do que na forma. Alheando-se este processo, o órgão ministerial não apenas deixa de contribuir para a consolidação do terceiro estágio de movimento de acesso à justiça, mas coloca em risco o posicionamento da instituição no contexto dos atores do sistema de justiça. (ALMEIDA, GAVRONSKI, 2014).

Acerca das reformas da administração da justiça, estas caminham por duas vias, de acordo com Santos (2005). Uma das vias trata das reformas no âmbito interno da justiça civil tradicional, ou, dito de outra forma, inclui o reforço dos poderes do juiz quanto à apreciação da prova e à condução do processo de acordo com os princípios da oralidade e da concentração. A outra via engloba a criação, de forma paralela à administração da justiça, de mecanismos de resolução de conflitos, pautados pela autonomia das partes, informalidade e celeridade.

Embora o Brasil esteja priorizando esta segunda via da reforma da administração da justiça, os debates da terceira onda de acesso à justiça priorizam a utilização da mediação, na maioria das vezes, subsequente à judicialização do conflito, o que dispensa a solução imposta pelo juiz, mas não a judicialização. Há também uma tendência em privilegiar a resolução de conflitos individuais em detrimento da perspectiva coletiva, devido à confusão entre o sistema de acesso à justiça e o sistema de acesso ao Judiciário por parte dos Poderes do Estado. Nesse viés, o II Pacto Republicano de Estado por um sistema de justiça mais acessível, ágil e efetivo estabelece o compromisso de fortalecer a mediação, mas é omisso em relação à utilização de instrumentos extrajudiciais como a audiência pública, a recomendação e o TAC, em sede de tutela coletiva ${ }^{28}$. (GAVRONSKI, ALMEIDA, 2014).

Apesar do exposto acima, em conformidade com a Resolução $n^{\circ} 125 / 2010$ do CNJ, que dispõe sobre a Política permanente de estímulo e aperfeiçoamento da mediação e dos demais mecanismos consensuais de resolução de conflitos no âmbito do Poder Judiciário, o Conselho Nacional do Ministério Público (CNMP), no exercício da competência prevista no artigo 130-A, §2 inciso I, da Constituição e do Regimento Interno, editou a Resolução $n^{\circ}$ 118/2014 para instituir a política nacional de incentivo à autocomposição no âmbito do MP. Essa Resolução teve por finalidade privilegiar a atuação preventiva dos seus membros, reduzir a litigiosidade e disseminar a cultura da paz, por meio do diálogo e da participação da sociedade civil.

O capítulo III da Resolução, denominado "Das Práticas Autocompositivas no Âmbito do MP", delineia em quais situações de conflito cada uma destas práticas autocompositivas poderá ser utilizada $^{29}$. A negociação é recomendada para os conflitos nos quais o Ministério Público atua como

\footnotetext{
${ }^{28}$ O sistema de acesso à justiça não se limita ao acesso ao Poder Judiciário.

${ }^{29}$ Artigo 13 da Resolução $n^{\circ} 118$ do CNMP (grifo da autora): “As práticas restaurativas são recomendadas nas
} 
parte na defesa de direitos da sociedade na condição de legitimado coletivo universal ou para resolver problemas relacionados à convênios, entre os próprios membros do MP e parecerias público-privadas (artigo $8^{\circ}$ da Resolução).

A mediação é recomendada para conflitos que envolvam "relações jurídicas nas quais é importante a direta e voluntária ação de ambas as partes divergentes". Seu campo de atuação é a prevenção e a resolução de conflitos, sejam estes judicializados ou não. No caso de acordo entre as partes, este poderá ser referendado pelo órgão ministerial ou encaminhado ao Poder Judiciário para a sua homologação. A Resolução também recomenda o sigilo das informações produzidas nas sessões de mediação, inclusive nas sessões privadas, exceto com autorização das partes ou violação das leis vigentes. Em conformidade com o princípio da imparcialidade, é vedado ao servidor ou membro que participar da mediação ser testemunha do caso ou atuar como advogado das partes, conforme determina o artigo $10, \S 2^{\circ}$, da Resolução.

Por fim, a conciliação é recomendada aos conflitos em que a intervenção do membro MP é para sugerir uma solução para o conflito. Ou seja, a conciliação é direcionada para os conflitos "que envolvam direitos ou interesses nas áreas de atuação do Ministério Público como órgão interveniente e nos quais sejam necessárias intervenções propondo soluções para a resolução das controvérsias ou dos conflitos", de acordo com o artigo 11 da Resolução.

A partir do delineamento de quais situações de conflitos os métodos autocompositivos podem ser prioritariamente utilizados, é possível extrair que a prática recomendada para a resolução dos conflitos ambientais é a negociação, porque nesta os membros do MP atuam como parte na proteção dos direitos da sociedade. Com isso, a Resolução deixa de explorar o potencial da mediação na área ambiental, em especial sob o viés da celeridade, prevenção de danos ambientais e comprometimento das partes com as obrigações assumidas.

Feita essa breve introdução acerca do órgão ministerial, é preciso abordar o conceito do perfil demandista dos seus membros frente ao perfil resolutivo, igualmente previsto pela Constituição. O perfil demandista é marcado pela atuação do MP no plano jurisdicional, vale dizer, sua atribuição está limitada ao ajuizamento de medidas judiciais. Consequentemente, a responsabilidade pela resolução do conflito é transferida ao Poder Judiciário, que nem sempre

situações para as quais seja viável a busca da reparação dos efeitos da infração por intermédio da harmonização entre o (s) seu (s) autor (es) e a (s) vítima (s), com o objetivo de restaurar o convívio social e a efetiva pacificação dos relacionamentos". Opta-se, devido à proximidade com o tema de pesquisa, por abordar a negociação, a mediação e a conciliação. 
consegue respondê-lo de forma adequada. Em síntese, o MP preponderantemente demandista apresenta as seguintes características ${ }^{30}$ (ALMEIDA, 2013; RODRIGUES, 2015, grifo da autora):
$\checkmark \quad$ O MP apenas reage aos fatos sociais;
$\checkmark \quad$ Assume uma postura burocrática;
$\checkmark \quad$ Distancia-se da sociedade;
$\checkmark \quad$ Perde a legitimidade democrática;
$\checkmark \quad$ É indiferente em relação aos resultados extraprocessuais;
$\checkmark \quad$ É essencial apenas à função jurisdicional do Estado; e
$\checkmark \quad$ Os conflitos são submetidos a uma lógica racional-legal.

No modelo resolutivo, o MP atua antes que os fatos se tornem conflituosos e faz uso dos mecanismos extrajudiciais para resolvê-los, sendo desnecessário demandar em um primeiro momento o Poder Judiciário. A postura pró-ativa dos membros do órgão ministerial aliada à resolução preventiva e extrajudicial contribui para que o Judiciário seja acionado tão somente $a$ ultima ratio. As principais características da dinâmica institucional resolutiva são assim sintetizadas $^{31}$. (RODRIGUES, 2015, grifo da autora):

$\checkmark$ Proatividade: em vez de reagir contra fatos já realizados, o MP antecipa-se à ocorrência do conflito, inspirado pelas atribuições extrajudiciais da instituição;

$\checkmark$ Dinamismo: uma instituição burocrática e formal é fadada a desaparecer dentro de uma sociedade dinâmica como a nossa. Diante dessa realidade, os seus membros precisam ser ágeis, dinâmicos e abertos às inovações ${ }^{32}$.

Intercambialidade: é preciso estabelecer um diálogo institucional interno para que seus membros possam adquirir ou trocar experiências;

$\checkmark$ Intersetorialidade: o potencial cooperativo das estruturas sociais, como a sociedade civil e as demais instituições, precisa ser explorado em favor do enfrentamento dos conflitos sociais cada vez mais complexos;

$\checkmark \quad$ Planejamento: é preciso um planejamento estratégico-institucional que possibilite um ajuste entre as demandas sociais e os resultados almejados pelo MP;

\footnotetext{
${ }^{30}$ No mesmo sentido, Machado (2000).

${ }^{31}$ Rodrigues (2015) sustenta que há um terceiro modelo de atuação do Ministério Público: o parecerista, ou seja, atuação como custos legis em ações não promovidas pelo órgão ministerial.

32 Nesse sentido, "toda instituição que se torna puramente defensiva num mundo em que as condições de existência, as técnicas de produção, as ideias recebidas e as inspirações dos povos se transformam rapidamente e são alteradas pelo próprio ritmo de uma vida diária que se recusa a ser reduzida a um simples ritual, acaba morrendo". (JULIEN, 1975, p. 117).
} 
Inovação: o promotor de justiça precisa fazer mais e melhor com menos recursos, ou seja, precisa ser criativo para prestar os serviços relacionados à instituição com ganho de eficiência;

Eficiência e gestão de resultados: o MP precisa buscar resultados relevantes para a sociedade.

Da mesma forma que a Resolução n 118/2014, a Recomendação n 54/2017 dispõe sobre o incentivo à atuação resolutiva do Ministério Público. Ela define a atuação resolutiva como aquela por meio do qual os seus membros têm uma atuação decisiva para prevenir ou solucionar o conflito de forma efetiva tanto na esfera judicial quanto na extrajudicial. Sempre que a via extrajudicial se mostrar capaz de viabilizar uma solução mais célere, econômica implementável e capaz de satisfazer as partes, esta deve ser priorizada pelos seus membros. Não basta o acordo celebrado ou o provimento jurisdicional favorável, é preciso que a solução seja efetivada (artigo $1^{\circ}, \S 1^{\circ}$, da Resolução).

A concretização do MP resolutivo exige uma instituição aparelhada tanto em termos de estrutura física quanto de estrutura humana. Neste último aspecto, a Recomendação reforça a necessidade de capacitação e aperfeiçoamento dos seus membros acerca da autocomposição de conflitos. Além do aperfeiçoamento, a tutela dos direitos difusos e coletivos exige um grau de conhecimento que não se restringe apenas ao Direito, mas abrangem outras áreas, como a economia, o que demanda uma formação crítica, humanista, multidisciplinar e interdisciplinar dos membros e dos servidores do MP33. (ALMEIDA; BELTRAME; ROMANO, 2014).

Diante do exposto, é possível trazer à tona algumas considerações finais sobre o tema abordado neste tópico:

$\checkmark \quad$ O modelo de atuação demandista ainda se faz presente no âmbito do MP;

$\checkmark \quad$ O estágio atual do movimento do acesso à justiça é incompatível com uma atuação do órgão ministerial formal, burocrática, lenta e despreocupada com a produção de resultados socialmente relevantes;

$\checkmark$ É preciso fomentar uma cultura institucional de entrega à sociedade de resultados concretos;

\footnotetext{
${ }^{33}$ Multidisciplinar "é uma simples associação de disciplinas que concorrem para uma realização comum, mas sem que cada disciplina tenha que modificar significativamente a sua própria visão das coisas e dos próprios métodos" (DELATTRE, 2006, p. 280). Já interdisciplinar "é o método de pesquisa e de ensino susceptível de fazer com que duas ou mais disciplinas interajam entre si, esta interação podendo ir da simples comunicação das ideias até a integração mútua dos conceitos, da epistemologia, da terminologia, da metodologia e dos procedimentos da pesquisa". (JAPIASSU; MARCONDES, 1993, p. 136).
} 
A capacitação e o aperfeiçoamento dos membros e servidores do MP na área dos mecanismos extrajudiciais é uma necessidade;

$\checkmark$ O perfil resolutivo dos membros do órgão ministerial é voltado para a resolução concreta das situações de inefetividade dos direitos cuja proteção é atribuída ao Ministério;

$\checkmark$ Esta atuação resolutiva do órgão ministerial requer a aproximação entre a instituição e a sociedade civil;

$\checkmark \mathrm{O}$ perfil resolutivo do MP é o que melhor se adéqua à área ambiental. Os danos que afetam o meio ambiente, na maioria das vezes, não são passíveis de reparação in natura, nesse sentido, restaria apenas uma tutela repressiva, a qual não responde de forma satisfatória à realização do direito.

、 A resolutividade do órgão ministerial se dá especialmente no campo extraprocessual e na atuação preventiva;

$\checkmark$ A atuação resolutiva do MP deve ser pautada pelo aos princípios "da máxima efetividade possível; participação; mínima formalidade necessária; criação e concretização dos direitos por meio do consenso; e complementaridade entre as técnicas extraprocessuais e processuais". (GAVRONSKI, 2010, p.274).

Por último, embora a Recomendação no 54 do CNMP explicite o fomento das práticas resolutivas por meio do aprimoramento das ferramentas já utilizadas no âmbito do Ministério Público, como os TACs e o inquérito civil, também há espaço para fomentar a utilização de outras ferramentas que valorizem a postura colaborativa, no lugar do embate; a construção de uma solução consensual, ao invés de uma solução por sentença do juiz; o comprometimento das partes com as medidas necessárias à concretização do direito, no lugar da indiferença por resultados.

Assim, o próximo tópico se destina a apresentar uma experiência pioneira de resolução extrajudicial de conflitos ambientais no âmbito do Ministério Público Estadual, a qual retrata o perfil resolutivo dos membros do órgão ministerial.

4.1 Resolução extrajudicial dos conflitos ambientais no âmbito do NUCAM: pesquisa realizada pelo Centro de Direito e Meio Ambiente (CDMA) da Fundação Getúlio Vargas do Rio de Janeiro (FGV/RJ)

No início de 2010, o MP/MG e o Banco Mundial firmaram um Termo de Cooperação Técnica, com previsão de investimentos no aperfeiçoamento institucional, para construir um novo modelo de gestão e resolução de conflitos ambientais. Os objetivos da parceria firmada no que tange à área ambiental são assim sintetizados. (SAMPAIO et al., 2016): 
$\checkmark \quad$ Aprimorar as técnicas de resolução de conflitos ambientais utilizadas pelo MP;
$\checkmark \quad$ Estudar metodologias para valorar os danos ao meio ambiente;
$\checkmark \quad$ Aprimorar a atuação do MP no processo de licenciamento ambiental; e
$\checkmark \quad$ Melhorar o sistema de intercâmbio de informações ambientais em Minas gerais. Resultando desta parceria, nasceu o projeto denominado "Reorganização do Ministério Público de Minas Gerais para atuação por bacias hidrográficas", ganhador em 2010 do Prêmio Innovare, na categoria Ministério Público - Desburocratização da Justiça. Essa experiência é pioneira por dois motivos. O primeiro é a criação do modelo de atuação do órgão ministerial por bacias hidrográficas e para a proteção do meio ambiente natural, cultural e artificial. A referida forma de organização foi inspirada no artigo de Antonio Herman de Vasconcellos e Benjamin, que defendia a premissa de que o meio ambiente não se organiza em comarcas tampouco em Municípios, assim a organização do MP deveria estar em conformidade com as territorialidades ambientais ${ }^{34}$. (BENJAMIN, 1998).

O segundo é a atuação preventiva, extrajudicial e resolutiva do MP na área ambiental. Do ponto de vista prático, essa atuação extrajudicial pode ocorrer de três formas. Na primeira, a pacificação do conflito pode ocorrer e se exaurir somente na via extrajudicial. Na segunda, a pacificação do conflito ocorre por meio dos mecanismos extrajudiciais, embora já tenha sido judicializado. Na terceira, a pacificação do conflito ocorre sem a interveniência do Judiciário, sendo requerida apenas a homologação do resultado na via judicial. (SAMPAIO et al., 2016).

Dessa forma, para conferir um tratamento especializado aos conflitos ambientais de alta complexidade, compreendido como os empreendimentos ou atividades de significativo impacto ambiental, a Resolução n 106/2012 da Procuradoria de Justiça instituiu, no âmbito do MP/MG, o Núcleo de Resolução dos Conflitos Ambientais ${ }^{35}$ (NUCAM). A dificuldade inicial enfrentada pelos membros do órgão ministerial foi a disponibilização do suporte técnico qualificado, necessário para subsidiar a atuação dos Promotores. Como forma de superá-la, os Coordenadores Regionais puderam viabilizar convênios com as Universidades e instituições de assessoramento técnico, bem

34 Conforme previsto no artigo $3^{\circ}$, IV da Lei Federal n.9.433/1997: “Constituem diretrizes gerais de ação para implementação da Política Nacional de Recursos Hídricos: [..] V- a articulação da gestão de recursos hídricos com a do uso do solo". Igualmente, o artigo 20 da Lei 8.171/1991 diz que "as bacias hidrográficas constituemse em unidades básicas de planejamento do uso, da conservação e da recuperação dos recursos naturais".

${ }^{35}$ A complexidade é determinada de forma objetiva pela classificação utilizada pelas normas que regulam o licenciamento ambiental (classe 5 ou 6), ou de forma discricionária, a partir de critérios como os impactos sociais, econômicos e culturais e também área de abrangência (SAMPAIO et al., 2016) 
como autorizar o adiantamento de despesas dos profissionais responsáveis pela elaboração dos laudos ${ }^{36}$. (MARTINS, 2010).

As etapas detalhadas do funcionamento do Projeto estão descritas abaixo. (SAMPAIO et al., 2016):

$\checkmark$ Criação das Promotorias Regionais e Temáticas;

$\checkmark \quad$ Aquisição e estruturação da sede das Promotorias Regionais;

$\checkmark \quad$ Designação de Promotores de Justiça para atuar exclusivamente na área ambiental;

$\checkmark \quad$ Designação para as Coordenadorias de assessores jurídicos e técnicos;

$\checkmark$ Convite ou convocação para realização de reuniões com a finalidade de definir as prioridades comuns de atuação;

Encaminhamento pelo Promotor/Coordenador de material de apoio ao Promotor de Justiça;

V Disponibilização do suporte técnico para atuação do Promotor de Justiça na defesa do meio ambiente; e

Apresentação de proposta de solução extrajudicial do conflito ao suposto autor da infração ambiental, que é convocado para reunião na sede da Promotoria Regional.

Dessa forma, a solicitação de apoio técnico e jurídico advinda de uma Promotoria é submetida à análise do NUCAM para verificar se o grau de complexidade do conflito pertence à classe 5 ou 6 do licenciamento ambiental. Uma vez aceito o pedido, é instaurado o procedimento administrativo, que poderá ser instruído por meio de procedimento próprio denominado de Procedimento de Apoio à Atividade Fim (PAAF) ou por meio do Inquérito Civil. Quando o pedido de apoio é instruído por meio do PAAF, o arquivamento é realizado pelo próprio núcleo. Se for instruído por inquérito civil, este retorna à Promotoria de origem para deliberação sobre o seu arquivamento e homologação do CNMP.

As potencialidades da experiência pioneira desenvolvida no âmbito do NUCAM são assim sintetizadas por Sampaio et al. (2016)):

$\checkmark \quad$ A resolução extrajudicial de conflitos como novo modelo de gestão do Ministério Público;

Celeridade e menor custo se comparado à interposição judicial;

Atuação preventiva da responsabilidade ambiental;

${ }^{36}$ O NUCAM dispõe de convênio com o Instituto Prístino, SOS Mata Atlântica, Instituto Vivendi. 
Segurança jurídica das relações ambientais, o que leva à redução da judicialização;

$\checkmark$ Redução da burocracia para a solução de conflitos ambientais;

$\checkmark$ Ampliação do acesso à justiça;

$\checkmark$ A resolução extrajudicial dos conflitos ambientais tem boa aceitação por parte da sociedade civil organizada, Estado e diversos segmentos do setor produtivo; e

$\checkmark \quad$ As condutas empresarias e sociais voltam-se para o desenvolvimento sustentável.

Apresentadas as potencialidades, é necessário apontar os desafios a serem enfrentados pelo NUCAM. O primeiro desafio é a superação do perfil demandista dos membros do MP. O segundo é a falta de incentivo à resolução negociada no âmbito das instituições públicas. $O$ terceiro é a necessidade de padronização dos procedimentos internos, como forma de garantir o seu funcionamento independentemente da alteração da equipe do NUCAM, bem como dos Promotores de Justiça. O último é a igualdade de condições entre o MP e as partes envolvidas no conflito ${ }^{37}$.

Feita essa introdução sobre o funcionamento do NUCAM, optou-se por apresentar os principais resultados da pesquisa empírica realizada pelo centro de Direito e Meio Ambiente (CDMA) da FGV/RJ e o NUCAM, pelo fato de ser uma experiência pioneira no âmbito do órgão ministerial, pois materializa a sua atuação preventiva e extrajudicial, bem como para obter subsídios que auxiliem no esclarecimento do tema de pesquisa. Quanto às ferramentas metodológicas, a pesquisa se utilizou do banco de dados e da aplicação de um questionário aos Promotores de Justiça do $\mathrm{MP} / \mathrm{MG}^{38}$. Outro esclarecimento é que o projeto desenvolvido pelo MP/MG ganha contornos de técnica de negociação em matéria ambiental, porque o membro do Parquet atua concomitantemente como moderador de conflitos e garantidor de direitos.

Inicia-se pela análise dos questionários quanto à composição institucional do MP/MG e a percepção de seus membros quanto à atuação extrajudicial da instituição. Em relação à composição

\footnotetext{
${ }^{37}$ Para Sampaio et al. (2016), a desigualdade ocorre em razão da natureza indisponível do direito fundamental ao meio ambiente ecologicamente equilibrado, da legitimação ativa do MP nas esferas civil e criminal e do poder investigatório do referido órgão.

${ }^{38} \mathrm{O}$ banco de dados foi escolhido porque possibilita o acompanhamento sistemático dos procedimentos instaurados no âmbito do NUCAM. A entrevista foi em formato de árvore, ou seja, "estrutura de perguntas que se combinam a partir de uma lógica pré-definida em relação ao tipo de resposta selecionada pelo questionado". Dos 879 Promotores de Justiça em atividade, no ano de 2014, apenas 431 deles responderam o questionário, o que representa que o conjunto amostral corresponde a $49,0 \%$ do total dos Promotores de Justiça ativos do MP/MG. (SAMPAIO et al., 2016, p. 119).
} 
de gênero da instituição, dos 431 Promotores que responderam a pesquisa, $71,5 \%$ são do sexo masculino, o que representa em termos absolutos 308 Promotores, e $28,5 \%$ são do sexo feminino. Outro dado revela que $86,9 \%$ dos entrevistados já atuaram em promotoria com atribuição ambiental, sendo que mais da metade deles atuou por período inferior a cinco anos. Somente 5,1\% dos Promotores de Justiça desempenharam atividades na área ambiental por mais de 20 anos.

Outro questionamento feito aos entrevistados mostrou que $60 \%$ deles já tinham realizado cursos sobre as técnicas extrajudiciais, o que em termos absoluto representa 256 Promotores de Justiça. Entre estes, $79,5 \%$ celebraram TAC e tão somente $10 \%$ solicitaram apoio ao Núcleo. Os dados revelam que os membros do órgão ministerial qualificados nessa área têm propensão a celebrar Termo de Ajustamento de Conduta, mas não exercem influência no pedido de apoio ao NUCAM. (SAMPAIO et al., 2016).

Além da composição institucional, outra parte do questionário voltou-se à visão dos Promotores em relação à utilização da via extrajudicial na resolução de conflitos ambientais. $\mathrm{A}$ maioria deles $(98,4 \%)$ respondeu que a solução extrajudicial é uma boa alternativa quando da instauração de um procedimento preparatório ou do inquérito civil, enquanto que apenas 1,6\% responderam que a solução extrajudicial não é melhor alternativa. Outra pergunta feita aos Promotores foi sobre os motivos pelos quais eles consideraram ou não a solução extrajudicial a melhor alternativa. Os motivos indicados pelos sete Promotores de Justiça que responderam "não" para a solução extrajudicial de conflito são. (SAMPAIO et al., 2016, grifo da autora):

$\checkmark \quad$ As empresas e os órgãos do Poder Executivo são relutantes em negociar com o MP;

$\checkmark$ A propositura da ACP é mais efetiva; e

$\checkmark \quad$ A legislação benéfica ao infrator estimula o descumprimento da lei.

Quanto aos motivos apontados pelos 420 Promotores de Justiça favoráveis à solução extrajudicial, destacam-se. (SAMPAIO et al., 2016, grifo da autora):

$\checkmark \quad$ A solução extrajudicial é mais célere e eficiente;

$\checkmark \quad$ O Ministério Público deve adotar como regra uma postura resolutiva;

$\checkmark$ A Ação Civil Pública é menos efetiva;

$\checkmark \quad$ Outros motivos: a propositura da ACP não significa a pacificação social do conflito e as ACPs manejadas raramente são julgadas pelo Poder Judiciário.

Sobre as respostas dos entrevistados, é necessário tecer três observações. A primeira é o fato de os entrevistados terem apontado a solução extrajudicial como melhor alternativa não apenas sob o viés quantitativo (celeridade), mas também qualitativo (eficiente). A segunda é o 
reconhecimento pelo próprio legitimado ativo de que a ACP nem sempre é a melhor alternativa. Conforme explicitado no tópico anterior, a ACP apresenta como fator negativo a demora na sua tramitação e dificuldades no acompanhamento do seu cumprimento. A última observação é que nenhum dos entrevistados apontou como óbice para a solução extrajudicial o fato de que, em matéria ambiental, os direitos são indisponíveis.

Com a finalidade de verificar se os meios extrajudiciais estavam sendo utilizados pelos Promotores de Justiça para resolver os conflitos ambientais, foi questionado se eles haviam celebrado Acordo/TAC. A quase totalidade dos entrevistados respondeu que sim $(83,9 \%)$ e apenas $16,1 \%$ respondeu que não havia utilizado Acordo/ TAC. Outro dado colhido refere-se à complexidade do conflito objeto do Acordo/TAC indicado por 62,7\% dos entrevistados ${ }^{39}$. Esses dados reafirmam a disposição dos entrevistados em resolver os conflitos ambientais de forma extrajudicial, bem como identifica a complexidade como uma das características deste tipo de conflito.

No início do texto, foi mencionado que os Promotores de Justiça podem solicitar apoio técnico e jurídico ao NUCAM no caso de conflitos ambientais de alta complexidade. Nesse sentido, questionou-se se eles haviam acionado ou não o Núcleo e os motivos para fazê-lo ou não. Dos 338 Promotores envolvidos em processos extrajudiciais na área ambiental, somente 8,6\% deles solicitaram empréstimo de apoio ao NUCAM, enquanto que $91,4 \%$ dos entrevistados não haviam solicitado apoio. As motivações indicadas para solicitar apoio ao NUCAM na celebração de Acordo/TAC foram. (SAMPAIO et al., 2016):

$\checkmark \quad$ Porque o NUCAM oferece mais recurso e estrutura;

$\checkmark \quad$ Pelo apoio técnico; e

$\checkmark \quad$ Porque quiseram prestigiar a iniciativa do Ministério Público ${ }^{40}$.

Os motivos para não terem solicitado apoio ao NUICAM na celebração de Acordo/TAC estão relacionados à informação, razão pela qual se entende que esta experiência precisa ser mais bem divulgada interna e externamente, para permitir a replicação desta prática exitosa de resolução extrajudicial de conflitos ambientais. Além disso, há espaço para ampliar o número de atendimento feito pelo NUCAM diante do número inexpressivo de Promotores que fizeram solicitação de apoio técnico e jurídico:

\footnotetext{
39 “93 Promotores de Justiça não responderam" (SAMPAIO et al., 2016, p. 141).

4093 Promotores de Justiça não responderam (SAMPAIO et al., 2016). Apenas 29 entrevistados responderam o questionamento sobre os motivos que os levaram a solicitar ou não apoio ao NUCAM.
} 
$\checkmark \quad$ O NUCAM não existia no momento da celebração dos Acordos/TACs;

$\checkmark \quad$ Porque não conheço o NUCAM e sua atuação;

$\checkmark \quad$ Porque não houve necessidade de apoio técnico;

$\checkmark \quad$ Porque é mais eficiente a negociação na própria Promotoria; e

$\checkmark \quad$ Porque a atribuição natural do Promotor de Justiça deve ser respeitada. (SAMPAIO et al., 2016).

Outro dado levantado pela pesquisa diz respeito à percepção dos entrevistados acerca da adequação da estrutura do Poder Judiciário para resolver os conflitos ambientais de forma célere e adequada. Nesse item, a quase totalidade dos entrevistados avaliou a estrutura estatal negativamente. Da mesma forma, 99,1\% deles apontaram que é necessário o aprimoramento dos instrumentos do MP na resolução dos conflitos ambientais. (SAMPAIO et al., 2016).

Assim, essas informações confirmam a atuação resolutiva e preventiva do NUCAM, que, por meio dos mecanismos extrajudiciais, resolve os conflitos ambientais com celeridade e qualidade, pois as soluções são tecnicamente mais adequadas. Assim, o órgão ministerial não apenas contribui para reduzir a judicialização, mas também entrega à sociedade um resultado concreto no que tange à proteção do meio ambiente. Esta forma de atuação do MP deveria ser estendida aos conflitos já judicializados, com a finalidade de evitar a demora na tramitação da de uma demanda judicial. Por fim, o projeto poderia melhor explorar a participação das outras partes na construção da solução para o conflito, que, por tratar-se de negociação, concentra nas mãos do MP a força para negociar, e não nas partes, como ocorre na mediação ${ }^{41}$.

\section{CONCLUSÃO}

O estudo Ações coletivas no Brasil: temas, atores e desafios realizados (CNJ, 2018) confirma o protagonismo do Ministério Público na área de defesa do meio ambiente, devido à titularidade do Inquérito Civil para fundamentar as ACPS e autoridade para firmar o TAC, assim como a expertise e condições institucionais no manejo desses mecanismos. Ficou evidenciado que o êxito destas ações está associado à capacidade do demandante de produzir provas materiais e técnicas do dano ambiental.

Outra conclusão refere-se à fiscalização do cumprimento dos acordos e decisões, em especial pela ausência de mecanismos institucionais voltados para esse fim. Evidenciou-se que a

\footnotetext{
${ }^{41}$ Partes: todas as pessoas, físicas ou jurídicas, afetadas pelo conflito.
} 
criação de varas especializadas no processamento de ações coletivas e a simplificação dos procedimentos são algumas das medidas que deveriam ser adotadas para melhorar a sua eficiência.

Apesar de a legislação brasileira prever a possibilidade da ACP ser proposta por cinco agentes distintos, o Ministério Público é o seu principal autor, conforme uma das conclusões do estudo dos dados levantados sobre a ACP junto às Câmaras reservadas ao meio ambiente no TJ/SP. Os principais demandados eram pessoas físicas proprietárias, o que pode ser justificada pelo fato de a Área de Preservação Permanente ser o objeto da ACP na maioria das ocorrências pesquisadas, seguida das empresas e órgãos ou instituições do governo. A maioria das decisões de primeira instância foram julgadas procedentes e confirmadas pelo referido Tribunal. Os demandados que não tiverem seu pedido acatado ou apenas de forma parcial são responsáveis pela interposição de apelação. Há uma tendência do TJ/SP em confirmar a decisão de primeiro grau das apelações interposta tanto pelos demandados quanto pelos demandantes.

Uma das experiências pioneiras em resolução negociada de conflitos ambientais foi aquela desenvolvida pelo MP/MG. A partir da aplicação do questionário aos Promotores do Estado, constatou-se que a maioria deles considera a solução extrajudicial a melhor alternativa porque esta é a via mais rápida e eficiente do que a judicial. Dos que responderam "não" para a solução extrajudicial, o principal motivo apontado foi a resistência dos órgãos do Poder Executivo em negociar com o órgão ministerial.

O Ministério Público brasileiro assumiu um papel destaque na viabilização da tutela jurisdicional dos direitos de segunda e terceira dimensão. Mas é preciso aprimorar a atuação da instituição na fase de implantação da terceira onda de acesso à justiça, centrada no resultado, e não na forma, no sentido de que a efetividade dos direitos deve ocorrer em tempo razoável, a baixo custo, com a participação e satisfação das partes. Frente a esses desafios, é preciso consolidar o perfil constitucional resolutivo da instituição, que atua no plano extrajurisdicional, no lugar do perfil demandista, que transfere ao Poder Judiciário à resolução do conflito.

\section{REFERÊNCIAS}

ALMEIDA, Gregório Assagra de. Direitos fundamentais e os principais fatores de legitimação social do Ministério Público no neoconstitucionalismo. In: ALMEIDA, Gregório Assagra de; SOARES JUNIOR, Jarbas. Teoria Geral do Ministério Público. Belo Horizonte: Del Rey, 2013.

ALMEIDA, Gregório Assagra de; BELTRAME, Martha Silva; ROMANO, Michel Betenjane. Novo perfil constitucional do Ministério Pública-negociação e mediação e a postura resolutiva e protagonista do Ministério Público na resolução consensual das controvérsias, conflitos e 
problemas. In: MINISTÉRIO DA JUSTIÇA (Escola Nacional de Mediação-ENAM). Manual de negociação e mediação para membros do Ministério Público. Brasília: Ministério da Justiça, 2014.

ALMEIDA, Gregório Assagra de; GAVRONSKI, Alexandre Amaral. O movimento de acesso à Justiça no Brasil e o Ministério Público. In: MINISTÉRIO DA JUSTIÇA (Escola Nacional de Mediação-ENAM). Manual de negociação e mediação para membros do Ministério Público. Brasília: Ministério da Justiça, 2014.

BARROS, Luís Fernando Bravo de; SPÍNOLA, Ana Luíza Silva. Conflitos socioambientais no Brasil: uma reflexão sobre a possibilidade transformativa dos procedimentos multiatores. In: PHILIPPI JR, Arlindo; SPÍNOLA, Ana Luíza Silva; FREITAS, Vladimir Passos de. Direito ambiental e sustentabilidade. São Paulo: Manole, 2016.

BENJAMIN, Antônio Herman de Vasconcellos. A insurreição da aldeia global contra o processo civil clássico. Apontamentos sobre a opressão e a libertação judiciais do meio ambiente e do consumidor In: MILARÉ, Edis. (Org.). Ação Civil Pública. Reminiscência e reflexões após dez anos de publicação. Rio de Janeiro: Editora Revista dos Tribunais, 1995.

BLACKBURN, W.; BRUCE, W. Mediating Environmental Conflicts. Theory and Practice. Westport: Quorum Books, 1995.

BOBBIO, Norberto; MATTEUCCI, Nicola; PASQUINO, Gianfranco Dicionário da Política. Brasília: Editora Universidade de Brasília, 1998.

BOREL, Rolain et al. Conflictos Socioambientales en América Latina. Un Intento de Tipología, Mapeo y Análisis Comparado de Casos. Serie: Del Conflicto a la Colaboración. Red Mesoamericana de Manejo de Conflictos. Costa Rica, 1999.

CEBOLA, Cátia Marques. A arbitragem no contexto ambiental e urbanístico. In: FONSECA, Isabel Celeste. (Coord.). A arbitragem administrativa e tributária. Coimbra, 2012.

CONSELHO NACIONAL DA JUSTIÇA. Justiça Pesquisa Direitos e Garantias Fundamentais Ações Coletivas no Brasil: temas, atores e desafios da tutela coletiva. Brasília: CNJ, 2018.

CONSELHO NACIONAL DO MINISTÉRIO PÚBLICO. Resolução № 118, de 10 de dezembro de 2014. Dispõe sobre a Politica Nacional de Incentivo à Autocomposição no âmbito do Ministério Público e dá outras providências. Disponível em:

<http://www.cnmp.mp.br/portal/images/Normas/Resolucoes/Resolu\%C3\%A7\%C3\%A3o_n\%C2\% BA_118_autocomposi\%C3\%A7\%C3\%A3o.pdf>. Acesso em: 13 nov. 2018.

COOLEY, John; LUBET, Steven. A advocacia de arbitragem. Tradução de René Locan, Brasília: Universidade de Brasília, 2001.

CORANTIOQUIA. Manejo de Conflictos Ambientales. Medellín, Colombia. 2001. 
DELATTRE, Pierre. Investigações interdisciplinares: objetivos e dificuldades. In: POMBO, Olga; GUIMARAES, Henrique Manuel; LEVY, Teresa. Interdisciplinaridade: antologia. Porto/PT: Campo das Letras, 2006.

DEUTSCH, Morton. A resolução do conflito: processos construtivos e destrutivos. In: AZEVEDO, André Gomma de (Org.). Estudos em Arbitragem, negociação e mediação. Brasília: Grupos de Pesquisa, 2004.

ELLINGSEN, Tanja; HAUGE, Wenge. Causal pathways to conflict. In: DIEHL, P.P, GLEDITISCH, N.P. Environmental Conflict. Boulder: Westview Press, 2001.

GALTUNG, Johan. Transcender e Transformar: uma introdução ao trabalho de conflitos. Tradução de: Antonio Carlos da Silva Rosa. São Paulo: Editora Palas Athena, 2007.

GAVRONSKI, Alexandre Amaral et al. Manual de Negociação e Mediação para membros do Ministério Público de Minas Gerais. Brasília: Ministério da Justiça, 2014.

JAPIASSU, Hilton; MARCONDES, Danilo. Dicionário básico de filosofia. Rio de Janeiro: Zahar, 1993.

LEDERACH, John Paul. Transformação de Conflitos. São Paulo: Atenas Editora, 2012. LEDESMA NARVÁEZ, Marianella. El Procedimiento Conciliatorio. Un Enfoque Teórico-Normativo. Edit. Gaceta Jurídica, 2000.

LIBISZEWSKI, Stephan. What is an Environmental Conflict? Meeting of the Environment and Conflicts Project. Zürich, April 1992.

LIMA, Márcia. Introdução aos métodos quantitativos em Ciências Sociais. In: ABDAL, Alexandre. Métodos de pesquisa em Ciências Sociais: Bloco Quantitativo. São Paulo: CEBRAP, 2016.

LITTLE, Paul E. Os conflitos socioambientais: um campo de estudo e ação política. In: BURSZTYN, Marcel (org.). A difícil sustentabilidade: política energética e conflitos ambientais. Rio de Janeiro: Garamond, p.107-122, 2001.

MARTINEZ GONZALEZ, Alfonso. Métodos alternativos en manejo de conflictos. aplicaciones em materia ambiental. México: SEMARNAP, PNUD. 1997.

MARTINS, Luciano Badini. Reorganização do Ministério Público de Minas Gerais para atuação por Bacias Hidrográficas. 2010. Disponível em:

<http://www.premioinnovare.com.br/praticas/l/reorganizacao-do-ministerio-publico-do-estadode-minas-gerais-para-a-atuacao-por-bacia-hidrografica-e-para-protecao-do-meio-ambientenatural-cultural-urbanistico>. Acesso em: 22 dez. 2017.

MILARÉ, Edis. Direito do Ambiente. São Paulo: Editora Saraiva, 2017.

MINAYO, María C. O desafio do conhecimento. Pesquisa qualitativa em saúde. São Paulo: Hucitec; Rio de. Janeiro: Abrasco, 2008. 
MINAYO, Maria Cecília de Souza. Amostragem e saturação em pesquisa qualitativa: consensos e controvérsias. Revista Pesquisa Qualitativa, São Paulo, v. 5, n. 7, p. 01-12, abril. 2017.

MINISTÉRIO PÚBLICO ESTADUAL DE MINAS GERAIS. Resolução PGJ no 106, de 6 de dezembro de 2012. Disponível em: <http://ws.mpmg.mp.br/biblio/informa/071218066.htm>. Acesso em: 22 dez. 2017.

MINISTÉRIO PÚBLICO FEDERAL. Relatório de resultados do Procurador-Geral da República: diálogo, unidade, transparência, profissionalismo, efetividade: 2015-2017. Ministério Público Federal. Brasília: MPF, 2017.

MIRRA, Álvaro Luiz Valery. Participação, processo civil e defesa do meio ambiente. São Paulo: Letras Jurídicas, 2011.

QUINTANA RAMÍREZ, Ana Patricia. El conflicto socioambiental y estrategias de manejo. s/d. Disponível em:

<http://www.fuhem.es/media/cdv/file/biblioteca/Conflictos_socioecologicos/conflicto_socioamb iental_estrategias\%20_manejo.pdf>. Acesso em: 10 jan. 2018.

RODRIGUES, Geisa de Assis. Ação civil pública e termo de ajustamento de conduta: teoria e prática. Rio de Janeiro: Forense, 2006.

SAMPAIO, Rômulo et al. Resolução consensual de conflitos ambientais um estudo de casos de experiência pioneira do Ministério Público de Minas Gerais. Rio de Janeiro: Lúmen Juris, 2016.

SANTANDREU, Alain; GUDYNAS, Eduardo. Ciudadanía en movimiento. Participación y conflictos ambientales. Montevideo: Editora Trilce/CLAES/Fundação Ebert, 1998.

SANTOS, Boaventura. Pelas Mãos de Alice: o social e o político na pós-modernidade. São Paul: Cortez, 2005.

YARN, Douglas. Dictionary of Conflict Resolution. São Francisco: Ed. Jossey-Bass Inc., 1999.

ZAMORRA Y CASTILLO, Niceto Alcalá. Processo, autocomposição e autodefesa. Cidade do México: Editora da Universidade Autónoma Nacional de México, 1991.

ZHOURI, Andréa et al. Desenvolviemnto, sustentabilidade e conflitos socioambientais. In: ZHOURI, Andréa et al. A insustentável leveza da política ambiental: desenvolvimento e conflitos socioambientais. Belo Horizonte: Autêntica Editora, 2005.

Trabalho enviado em 10 de janeiro de 2019

Aceito em 28 de novembro de 2019 